\title{
Temperature Changes in India
}

\section{Coordinating Lead Authors}

J. Sanjay, Indian Institute of Tropical Meteorology (IITM-MoES), Pune, India, e-mail: sanjay@tropmet.res.in (corresponding author)

J. V. Revadekar, Indian Institute of Tropical Meteorology (IITM-MoES), Pune, India

\section{Lead Authors}

M. V. S. Ramarao, Indian Institute of Tropical Meteorology (IITM-MoES), Pune, India

H. Borgaonkar, Indian Institute of Tropical Meteorology (IITM-MoES), Pune, India

S. Sengupta, Indian Institute of Tropical Meteorology (IITM-MoES), Pune, India D. R. Kothawale, Indian Institute of Tropical Meteorology (IITM-MoES), Pune, India Jayashri Patel, Indian Institute of Tropical Meteorology (IITM-MoES), Pune, India R. Mahesh, Indian Institute of Tropical Meteorology (IITM-MoES), Pune, India

S. Ingle, Indian Institute of Tropical Meteorology (IITM-MoES), Pune, India

\section{Review Editors}

K. AchutaRao, Centre for Atmospheric Sciences, Indian Institute of Technology Delhi, New Delhi, India A. K. Srivastava, India Meteorological Department (IMD-MoES), Pune, India

J. V. Ratnam, Application Laboratory, Japan Agency for Marine Earth Science and Technology (JAMSTEC), Yokosuka, Japan

\section{Corresponding Author}

J. Sanjay, Indian Institute of Tropical Meteorology (IITM-MoES), Pune, India, e-mail: sanjay@tropmet.res.in

The original version of this chapter was revised. On page 40, line 5 the word "business-as-usual" has been changed. The correction to this chapter is available at https://doi.org/10.1007/978-981-15-4327-2_13 


\section{Key Messages}

- Annual mean, maximum and minimum temperatures averaged over India during 1986-2015 show significant warming trend of $0.15{ }^{\circ} \mathrm{C}, 0.15^{\circ} \mathrm{C}$ and $0.13{ }^{\circ} \mathrm{C}$ per decade, respectively (high confidence), which is consistent with dendroclimatic studies.

- Pre-monsoon temperatures displayed the highest warming trend followed by post-monsoon and monsoon seasons.

- The frequency of warm extremes over India has increased during 1951-2015, with accelerated warming trends during the recent 30 year period 1986-2015 (high confidence). Significant warming is observed for the warmest day, warmest night and coldest night since 1986.

- The CORDEX mean surface air temperature change over India for the mid-term (long-term) period 2040-2069 (2070-2099) relative to $1976-2005$ is projected to be in the range of $1.39-2.70{ }^{\circ} \mathrm{C}\left(1.33-4.44{ }^{\circ} \mathrm{C}\right)$ across greenhouse gas warming scenarios. The ranges of these Indian mean temperature trends are broadly consistent with the CMIP5 based estimates.

- The frequency and intensity of warm days and warm nights are projected to increase over India in the next decades, while that of cold days and cold nights will decrease (high confidence). These changes will be more pronounced for cold nights and warm nights.

- The pre-monsoon season heatwave frequency, duration, intensity and areal coverage over India are projected to substantially increase during the twenty-first century (high confidence).

\subsection{Introduction}

Temperature is an essential climate quantity that directly affects human and natural systems. The global mean surface temperature is a key indicator of climate change because it increases quasi-linearly with cumulative greenhouse gas emissions as documented in multiple assessment reports of the Intergovernmental Panel on Climate Change (IPCC) including the most recent Fifth Assessment Report (AR5; IPCC 2013). This chapter assesses observed and projected changes in the mean and extreme temperature over India. The surface air temperature, typically measured at $2 \mathrm{~m}$ above the ground, varies from one region to another within India. This temperature also fluctuates naturally in interannual and decadal time scales in the background of human-induced changes in the climate. One of the important contributors of the observed changes in temperature not caused by human activities is the natural internal climate variability, which refers to the chaotic short-term fluctuations around the mean climate over a region or at a location. This includes phenomena such as the variability in the El Nino-Southern Oscillation (ENSO). The presence of internal variability places fundamental limits on the accuracy with which future temperature can be projected. The internal variability becomes larger when averaging results over smaller areas, which may lead to larger uncertainty in projections at the Indian country scale, relative to that at a global scale (Collins et al. 2013).

The temperature projections are obtained by driving climate models with different future forcing scenarios. These projections include the response of the climate system to external forcing (e.g. changing greenhouse gas concentrations), internal variability and uncertainties associated with differences between models. The multi-model ensemble mean averages out the internal variability and model differences to a large extent and provides an estimate of the response of the climate system to forcing.

\subsection{Observed Temperature Changes Over India}

A significant observed warming trend in all India averaged annual mean surface air temperature for the long-term period 1901-2010 was assessed using the estimates derived from the India Meteorological Department (IMD) gridded monthly station data (Srivastava et al. 2017). This assessment also documented several past studies which reported the variability and trends in temperature over India. In this section, the observed temperature changes over India for the more recent three decades between 1986 and 2015 are assessed using the estimates derived from the IMD gridded daily station data.

\subsubsection{Mean Temperature}

The mean temperature over India has warmed from the mid-twentieth century (Fig. 2.1), with an increased rate of warming of $0.15^{\circ} \mathrm{C}, 0.15^{\circ} \mathrm{C}$ and $0.13{ }^{\circ} \mathrm{C}$ per decade for the annual mean, maximum and minimum temperatures, respectively, between 1986 and 2015 (Table 2.1).

The warming is not uniform across the seasons, with considerably more warming in the pre-monsoon season (March-May; MAM) than in other seasons. The rate of warming of $0.26{ }^{\circ} \mathrm{C}, 0.29{ }^{\circ} \mathrm{C}$ and $0.20{ }^{\circ} \mathrm{C}$ per decade for the pre-monsoon season mean, maximum and minimum temperatures, respectively, between 1986 and 2015 are relatively higher than that for the respective annual values (see 


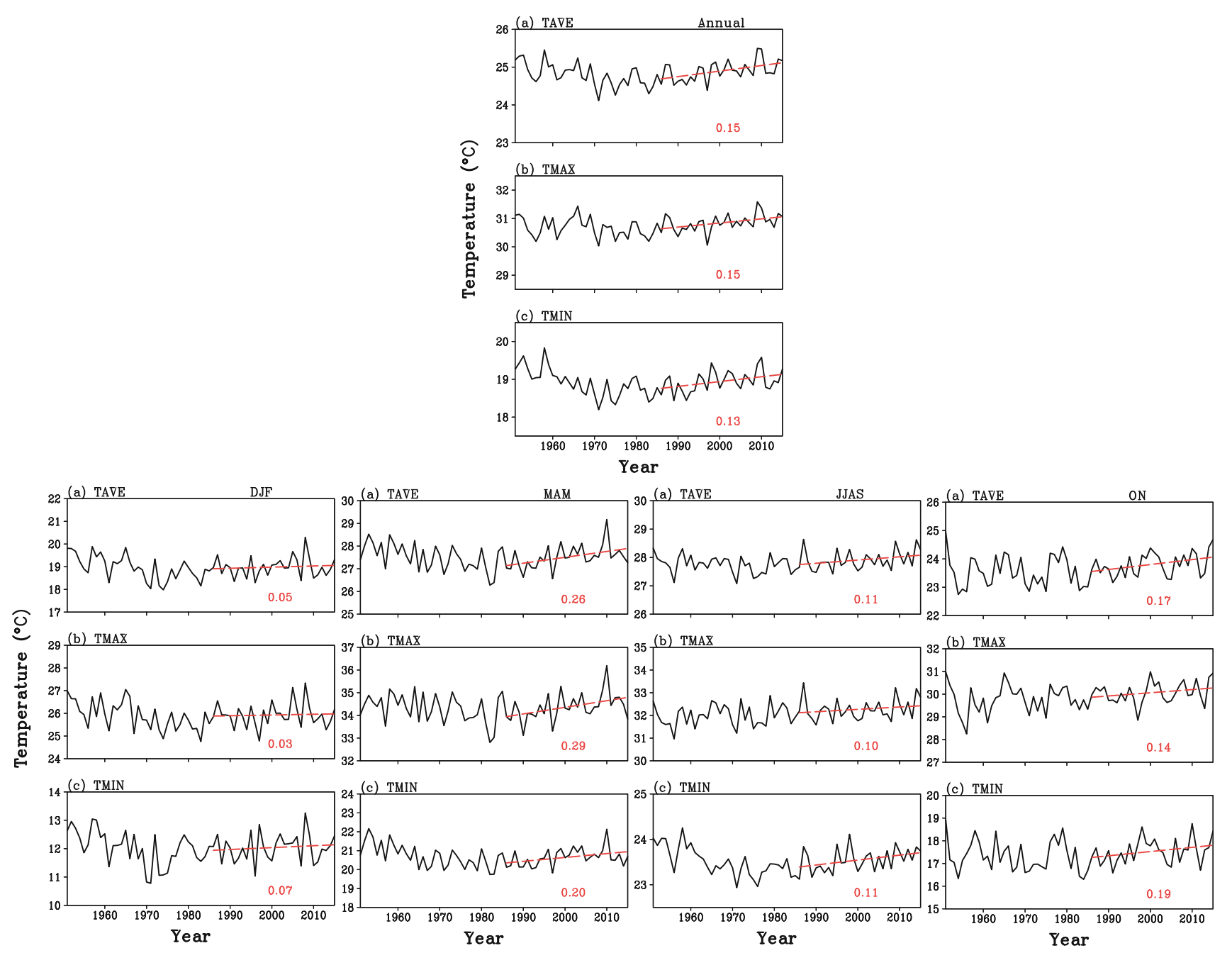

Fig. 2.1 Time-series of all India averaged (top panel) annual and (bottom panels) seasonal a mean, b maximum, and $\mathbf{c}$ minimum surface air temperatures between 1951 and 2015. Estimates are derived from the IMD daily gridded station data. Recent changes are computed based

on linear trends (dashed red line) over the 30-year period 1986-2015. The rate of warming during this period in ${ }^{\circ} \mathrm{C}$ per decade is shown below the trend lines. The $90 \%$ confidence intervals for these trend estimates are assessed in Table 2.1

Table 2.1 Observed changes in India land mean annual and seasonal surface air temperature between 1986 and 2015

\begin{tabular}{l|l|l|l}
\hline \multirow{2}{*}{ Season } & \multicolumn{2}{l}{ Temperature trends $1986-2015\left({ }^{\circ}\right.$ C per decade $)$} & Minimum \\
\cline { 2 - 4 } & Mean & Maximum & $\mathbf{0 . 1 3}^{*} \pm 0.10$ \\
\hline Annual & $\mathbf{0 . 1 5}^{*} \pm 0.09$ & $\mathbf{0 . 1 5}^{*} \pm 0.10$ & $0.07 \pm 0.18$ \\
\hline Winter (Dec-Feb) & $0.05 \pm 0.16$ & $0.03 \pm 0.20$ & $\mathbf{0 . 2 0}^{*} \pm 0.16$ \\
\hline Pre-monsoon (Mar-May) & $\mathbf{0 . 2 6}^{*} \pm 0.17$ & $\mathbf{0 . 2 9}^{*} \pm 0.20$ & $\mathbf{0 . 1 1}^{*} \pm 0.08$ \\
\hline Monsoon (Jun-Sep) & $0.11 \pm 0.12$ & $0.10 \pm 0.17$ & $0.19 \pm 0.20$ \\
\hline Post-monsoon (Oct-Nov) & $0.17 \pm 0.17$ & $0.14 \pm 0.22$ & \\
\hline
\end{tabular}

Estimates are derived from the IMD gridded station data. Changes are represented by linear trend ${ }^{\mathrm{a}}$ estimates $\left({ }^{\circ} \mathrm{C}\right.$ per decade) and $90 \%$ confidence intervals. Bold values with star sign (*) indicate that trend is significant (i.e. a trend of zero lies outside the $90 \%$ confidence interval)

${ }^{\mathrm{a}} \mathrm{A}$ linear trend model that allows for first-order autocorrelation in the residuals is adopted following IPCC AR5 (Hartmann et al. 2013)

Fig. 2.1 and Table 2.1). These changes in temperatures are statistically significant at the $90 \%$ confidence level. This behaviour of temperature changes is broadly consistent with the long-term variations and trends among the various global and regional gridded temperature estimates derived with different approaches (see Fig. 2.2 and Table 2.2). 
Fig. 2.2 Indian annual average land surface air temperature anomalies relative to $1981-2010$ climatology in the observed datasets (see details in Table 2.2)

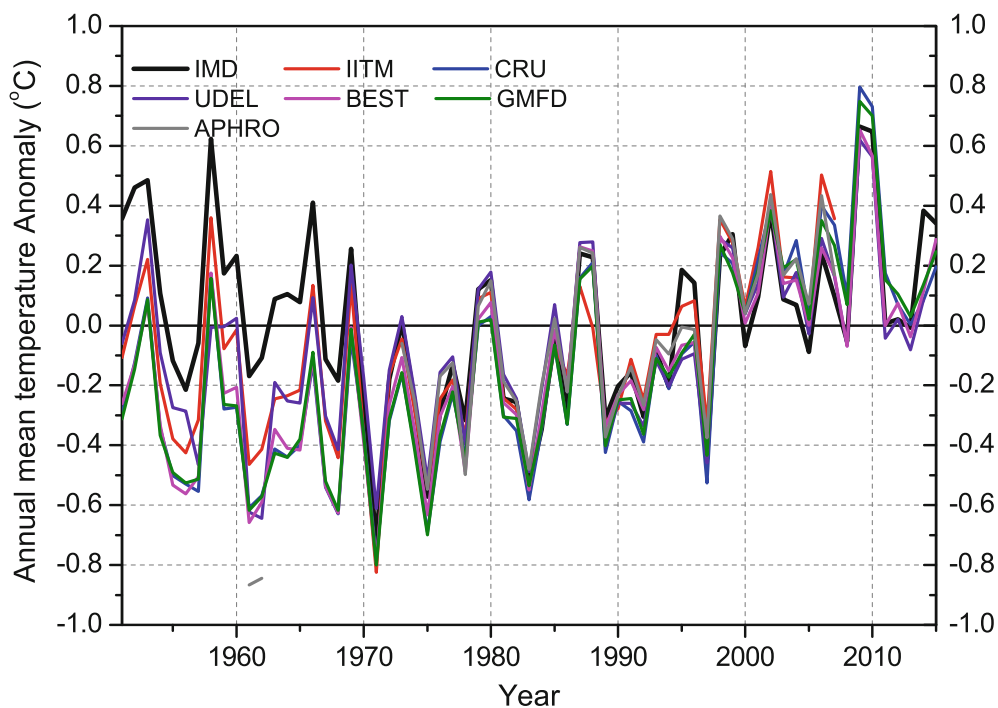

\begin{tabular}{|c|c|c|}
\hline Temperature dataset & Data resolution & $\begin{array}{l}\text { Indian annual mean } \\
\text { temperature trends }\left({ }^{\circ} \mathrm{C}\right. \\
\text { per decade) } 1986-2015\end{array}$ \\
\hline $\begin{array}{l}\text { India Meteorological Department } \\
\text { (IMD; Srivastava et al. 2017) }\end{array}$ & $\begin{array}{l}\text { 1951-2015; daily; } 395 \text { stations } \\
\text { over India; } 1.0^{\circ} \times 1.0^{\circ} \text { gridded }\end{array}$ & 0.15 \\
\hline $\begin{array}{l}\text { Climate Research Unit (CRU; Harris } \\
\text { et al. 2014) }\end{array}$ & $\begin{array}{l}\text { 1901-2016; monthly; global; } \\
0.5^{\circ} \times 0.5^{\circ} \text { gridded }\end{array}$ & 0.20 \\
\hline $\begin{array}{l}\text { University of Delaware (UDEL; } \\
\text { Peterson et al. 1998) }\end{array}$ & $\begin{array}{l}\text { 1901-2014; monthly; global; } \\
0.5^{\circ} \times 0.5^{\circ} \text { gridded }\end{array}$ & 0.13 \\
\hline $\begin{array}{l}\text { Berkeley Earth (BEST; Rhode et al. } \\
\text { 2013) }\end{array}$ & $\begin{array}{l}1750-2017 ; \text { monthly; global; } \\
1.0^{\circ} \times 1.0^{\circ} \text { gridded }\end{array}$ & 0.13 \\
\hline \multirow[t]{2}{*}{$\begin{array}{l}\text { Global Meteorological Forcing Dataset } \\
\text { (GMFD; Sheffield et al. 2006) }\end{array}$} & $\begin{array}{l}\text { 1948-2016; daily; global; } \\
\text { blended reanalysis with } \\
\text { observations; } 0.25^{\circ} \times 0.25^{\circ} \\
\text { gridded }\end{array}$ & 0.19 \\
\hline & & 1986-2007 \\
\hline $\begin{array}{l}\text { Indian Institute of Tropical } \\
\text { Meteorology (IITM; Kothawale et al. } \\
\text { 2010a, b) }\end{array}$ & $\begin{array}{l}\text { 1901-2007; monthly; } 121 \\
\text { stations over India; } 0.5^{\circ} \times 0.5^{\circ} \\
\text { gridded }\end{array}$ & 0.26 \\
\hline $\begin{array}{l}\text { Asian Precipitation-Highly Resolved } \\
\text { Observational Data Integration Towards } \\
\text { Evaluation (APHRODITE; Yasutomi } \\
\text { et al. 2011) }\end{array}$ & $\begin{array}{l}\text { 1961-2007; daily; over Asia; } \\
0.25^{\circ} \times 0.25^{\circ} \text { gridded }\end{array}$ & 0.21 \\
\hline
\end{tabular}

Table 2.2 Observed annual warming in India averaged surface air temperature in various global and regional datasets during 1986-2015
These long-term changes in surface air temperature over India during the twentieth century also broadly agree with earlier assessments (e.g. Rupa Kumar et al. 1994; Sen Roy and Balling 2005; Kothawale and Rupa Kumar 2005; Srivastava et al. 2009; Kothawale et al. 2010a; Jain and Kumar 2012; Rai et al. 2012; Vinnarasi et al. 2017; Kothawale et al. 2016; Kulkarni et al. 2017; Srivastava et al. 2017, 2019). Indian annual mean land surface air temperatures have warmed by $0.6{ }^{\circ} \mathrm{C}$ century $^{-1}$ between 1901 and 2018 (Srivastava et al.
2019). All India mean annual tropospheric temperature measured by radiosonde stations also showed an increasing trend from the surface to $500 \mathrm{hPa}$ during the period 1971-2015 (Kothawale and Singh 2017). A similar warming trend is revealed by dendroclimatic studies over the eastern Himalaya including Sikkim and Bhutan in recent decades (Krusic et al. 2015; Yadava et al. 2015; Borgaonkar et al. 2018). Further details on the long-term changes of temperature over India based on paleoclimatic proxies are provided in Box 2.1. 


\section{Box 2.1 Trends Based on Tree-Ring Proxies}

Palaeoclimatic records of temperature over monsoon Asia are limited and mainly based on the tree-ring proxies from the Himalayan region. Tree-ring based reconstructions of summer climate (temperature and rainfall) of Indian Himalaya, Nepal, Tibet, Karakoram region of Himalaya did not show significant increasing or decreasing trend during the past three to four centuries (Esper et al. 2002; Hughes 2001; Borgaonkar et al. 1994, 1996; Pant et al. 1998; Yadav et al. 1999; Cook et al. 2003; Thapa et al. 2015; Wu and Shao 1995). These reconstructions also indicated that the Little Ice Age (LIA) phenomenon was not prominent over this part of the Himalaya. However, few warm and cold epochs were observed over the region. A millennium-long mean summer temperature reconstruction from the monsoon-shadow zone in the western Himalaya (Yadav et al. 2011) indicated warming (Eleventhfifteenth century) and cooling episodes (Fiftieth-nineteenth century) followed by a warming trend in the twentieth century. Higher growth in recent few decades detected in the high altitude tree-ring chronology has been noticed coinciding with the warming trend and rapid retreat of the Himalayan glaciers (Borgaonkar et al. 2009, 2011).

Dendroclimatic studies over the eastern Himalaya including Sikkim and Bhutan have indicated a warming trend in recent decades (Yadava et al. 2015; Borgaonkar et al. 2018; Krusic et al 2015). The reconstructed mean late-summer (July-August-September) temperature showed warming since the 1930s, with 1996-2005 being the warmest in context of the past $\sim 150$ years (Yadava et al. 2015). Figure 2.3 shows the reconstructed late-summer temperature of Sikkim with a slight cooling trend since 1705 C.E. and noticeable increasing trend from 1850 C.E.
On a longer time scale, the first evidence of cooling during the Younger Dryas was provided by mineral magnetic susceptibility data and elemental concentrations that reveal a high around $13 \pm 2$ to $11 \pm 1 \mathrm{ka}$ (Juyal et al. 2009). The biochemical data of the Mansar Lake sediments, Lesser Himalaya indicated a hot and wet climate regime during the early Holocene and a dry and cold one during the late Holocene period (Das et al. 2010).

The observed warming is also unevenly distributed across India (Fig. 2.4). The largest increase in the annual mean temperature of more than $0.2{ }^{\circ} \mathrm{C}$ per decade are observed in some areas of north India between 1986 and 2015. The warming is much weaker in the southern peninsula, with mean temperature increase in some parts of the west coast lesser than $0.1{ }^{\circ} \mathrm{C}$ per decade. The winter warming is limited to peninsular India. The pre-monsoon season shows predominant warming of more than $0.5{ }^{\circ} \mathrm{C}$ per decade over north India. The summer monsoon season warming is confined to the eastern parts of the Indo-Gangetic plains and adjoining central India. The post-monsoon season warming pattern is similar to the pre-monsoon season, but with smaller magnitude and more uniformly distributed across the country than for other seasons. These estimates of warming across India based on simple linear trends are found to be, in general, similar to the earlier assessments of the temperature trends derived using non-stationary approach (Vinnarasi et al. 2017).

The all India averaged annual mean temperature increases due to greenhouse gas forcing outweighs the observed decrease in solar radiation (solar dimming; Padma Kumari et al. 2007). The radiative forcing is more effective in altering the strength of hydrological cycle than thermal forcing due to changes in the greenhouse gases (Padma Kumari and Goswami 2010; Soni et al. 2012; Padma Kumari et al. 2013).

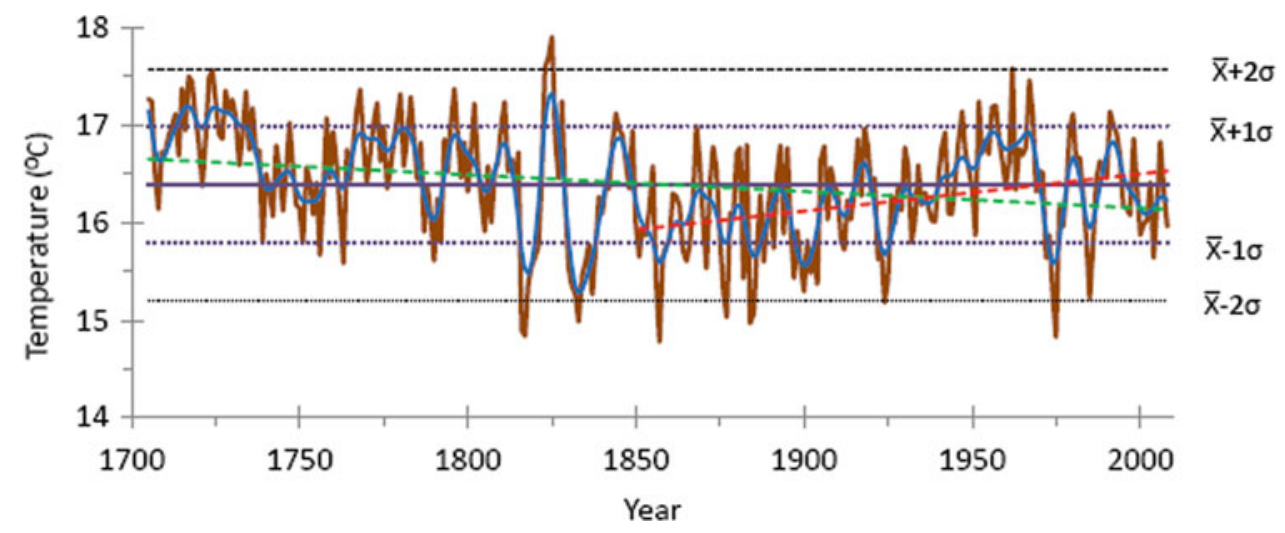

Fig. 2.3 Reconstructed late-summer (July-September) temperature of Sikkim from 1705-2008 C.E. (Brown line). The blue line indicates low-frequency variations at the decadal scale. Green- and red-dotted lines indicate a trend for full reconstructed period and for the period 1850-2008 C.E., respectively (Borgaonkar et al. 2018) 

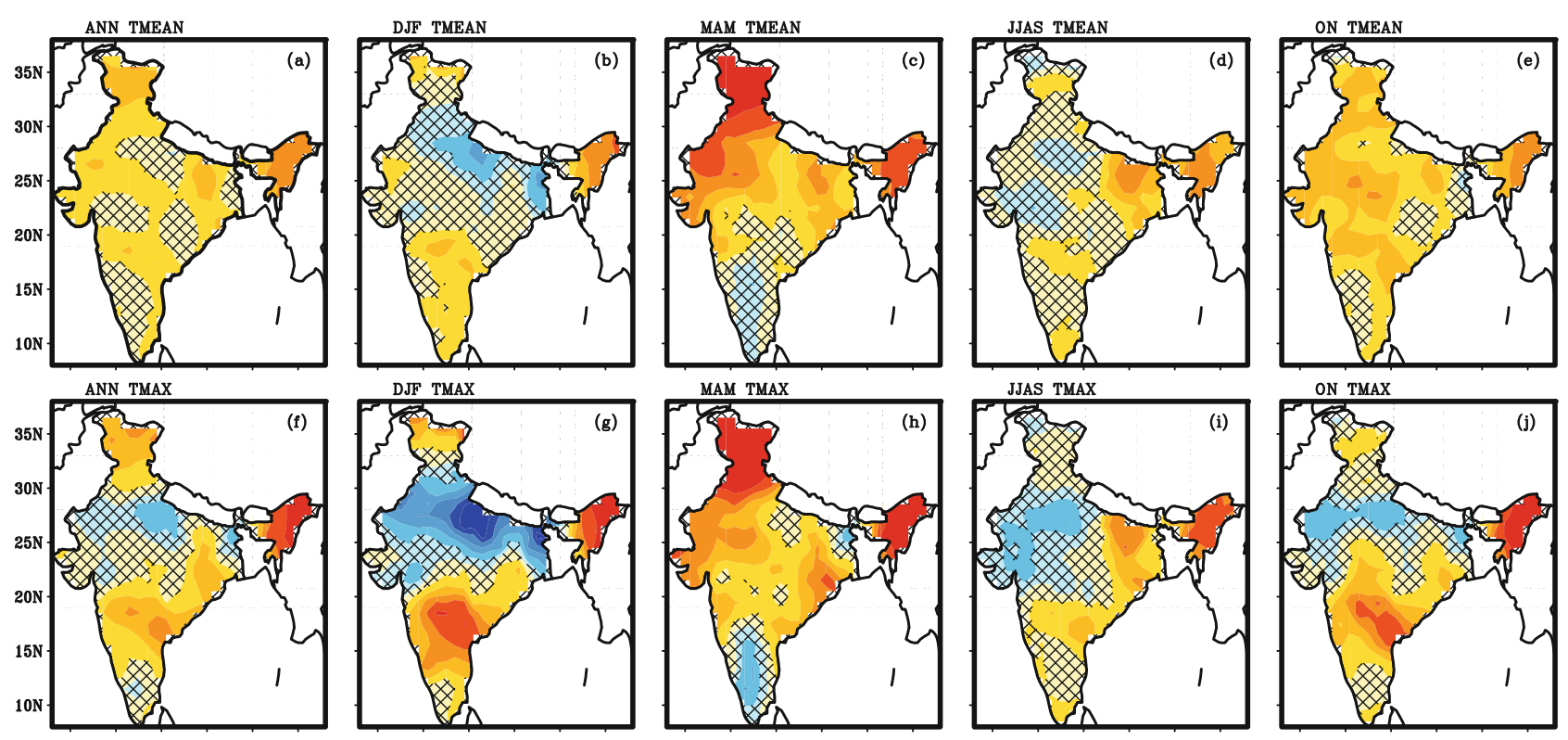

MAM TMAX

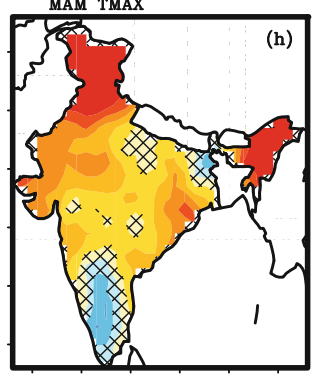

JJAS TMAX

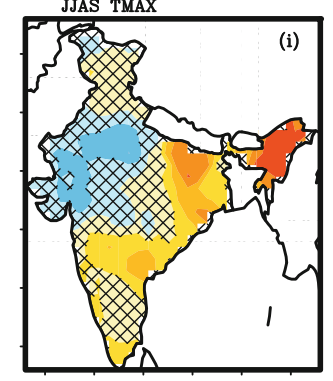

ON TMAX
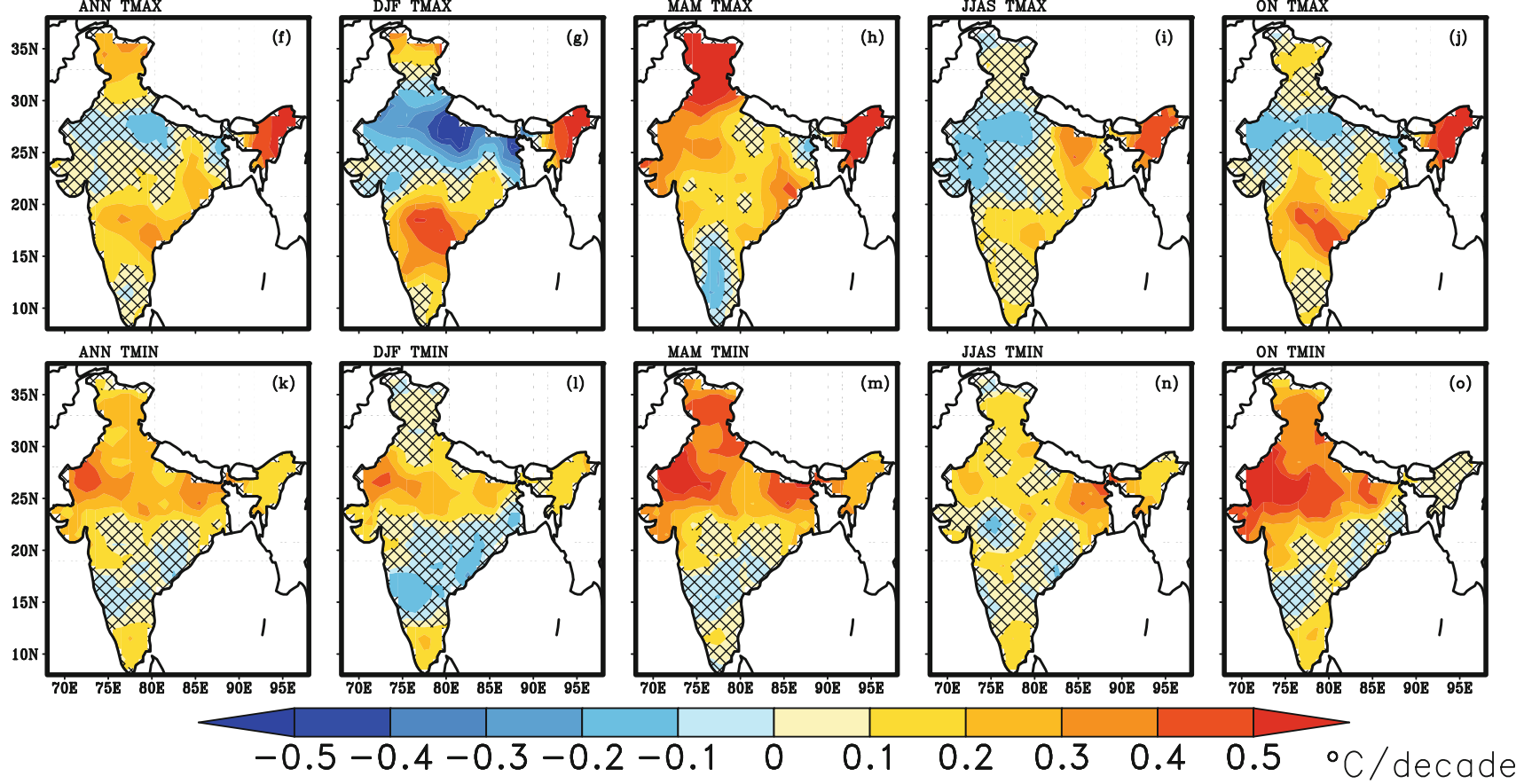

Fig. 2.4 Spatial distribution of observed annual and seasonal trends $\left({ }^{\circ} \mathrm{C}\right.$ per decade) for (top panel) mean, (middle panel) maximum and (bottom panel) minimum temperatures in (left to right panels) annual $(\mathrm{ANN})$, winter (December-February, DJF), pre-monsoon (March-May,

MAM), monsoon (June-September, JJAS) and post-monsoon (October-November, ON) seasons during the period 1986-2015. The grid boxes are hatched where the trends are insignificant (i.e. a trend of zero lies inside the $95 \%$ confidence interval)

The amount of water vapour in the atmosphere is expected to increase at a rate governed by the ClausiusClapeyron $\left(\sim 7 \%{ }^{\circ} \mathrm{C}^{-1}\right)$ under conditions of warming (Willett et al. 2007; Boucher et al. 2013). The all India averaged annual and seasonal mean specific humidity and relative humidity are found to be increasing significantly for both gridded observations (HadISDH, Willet et al. 2014) and reanalysis (ERA-Interim, Dee et al. 2011) datasets during the period 1979-2015 (Fig. 2.5 and Table 2.3).

The estimated magnitude of the annual specific humidity trend is similar for both datasets and is found to be comparable with the earlier assessment using IMD station data (Mukhopadhyay et al. 2017). The significant increasing trend in specific humidity assessed during the pre-monsoon season is consistent with the largest surface warming trend found for this season (see Table 2.1). Past studies had also reported a rise in the moisture content of the atmosphere associated with warming over the Indian region (Krishnan et al. 2016; Mukhopadhyay et al. 2017). This increased water vapour under conditions of regional warming may lead to significant positive feedback on human-induced climate change, as water vapour is the most important contributor to the natural greenhouse effect (Willett et al. 2007; Boucher et al. 2013).

\subsubsection{Causes of Observed Changes}

The surface air temperature changes over India between 1956 and 2005 are attributed to anthropogenic forcing mostly by greenhouse gases and partially offset by other anthropogenic forcings including aerosols and land use land cover change (Dileepkumar et al. 2018). The observed changes in maximum temperature during the post-monsoon 
Fig. 2.5 Time-series of all India averaged annual (left panels) specific humidity and (right panels) relative humidity from (top panels) HadISDH dataset and (bottom panels) ERA-Interim reanalysis for the period 19792015. The dashed blue lines indicate the linear trend for the period 1979-2015. The rate of change during this period is shown below the trend line. The $90 \%$ confidence intervals for these trend estimates are assessed in Table 2.3
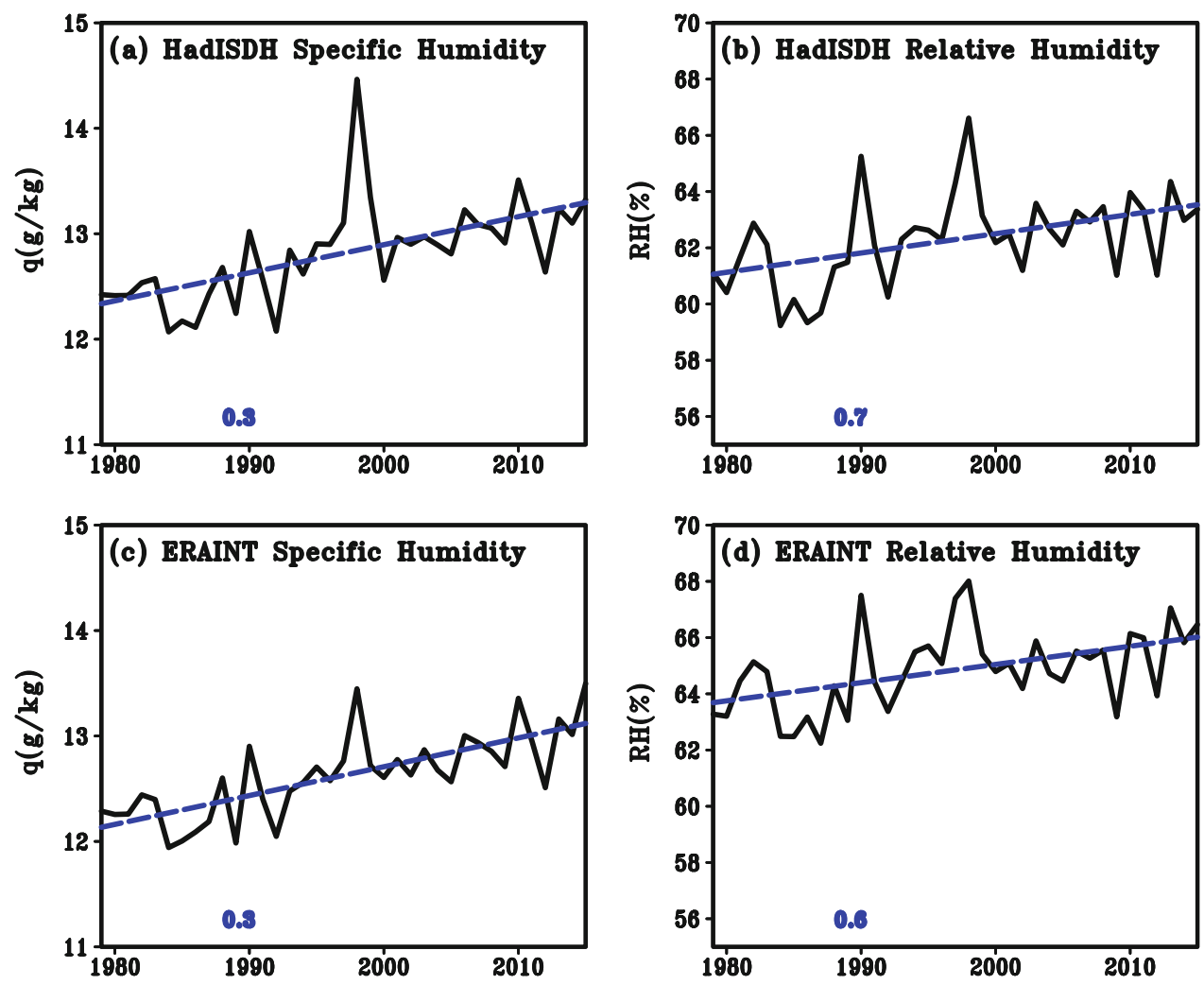

Table 2.3 Observed changes in India land mean annual and seasonal surface specific humidity and relative humidity between 1979 and 2015

\begin{tabular}{l|l|l|l|l}
\hline \multirow{2}{*}{ Season } & \multicolumn{2}{|l|}{$\begin{array}{l}\text { Specific humidity trends 1979- } \\
\text { 2015 }\left(\mathrm{g} \mathrm{kg}^{-1} \text { per decade }\right)\end{array}$} & \multicolumn{2}{l}{$\begin{array}{l}\text { Relative humidity trends 1979- } \\
\text { 2015 } \% \text { per decade })\end{array}$} \\
\cline { 2 - 5 } & HadISDH & ERA-interim & HadISDH & ERA-interim \\
\hline Annual & $\mathbf{0 . 2 7}^{*} \pm 0.13$ & $\mathbf{0 . 2 7}^{*} \pm 0.07$ & $\mathbf{0 . 6 9}^{*} \pm 0.48$ & $\mathbf{0 . 6 5}^{*} \pm 0.40$ \\
\hline Winter (Dec-Feb) & $\mathbf{0 . 2 0}^{*} \pm 0.10$ & $\mathbf{0 . 2 0}^{*} \pm 0.10$ & $\mathbf{0 . 8 6}^{*} \pm 0.54$ & $\mathbf{0 . 7 5}^{*} \pm 0.60$ \\
\hline Pre-monsoon (Mar-May) & $\mathbf{0 . 3 7}^{*} \pm 0.11$ & $\mathbf{0 . 3 6}^{*} \pm 0.11$ & $\mathbf{0 . 7 9}^{*} \pm 0.58$ & $\mathbf{0 . 8 5}^{*} \pm 0.64$ \\
\hline Monsoon (Jun-Sep) & $\mathbf{0 . 2 2}^{*} \pm 0.11$ & $\mathbf{0 . 2 5}^{*} \pm 0.09$ & $0.47 \pm 0.60$ & $0.45 \pm 0.51$ \\
\hline Post-monsoon (Oct-Nov) & $\mathbf{0 . 3 3}^{*} \pm 0.25$ & $\mathbf{0 . 3 7}^{*} \pm 0.16$ & $1.00 \pm 1.08$ & $\mathbf{0 . 8 6}^{*} \pm 0.79$ \\
\hline
\end{tabular}

Estimates are derived from the HadISDH dataset and ERA-Interim reanalysis. Trends and significance have been calculated as in Table 2.1. Bold values with star sign (*) indicate that trend is significant (i.e. a trend of zero lies outside the $90 \%$ confidence interval)

and minimum temperature during the pre-monsoon and monsoon seasons in South India during 1950-2005 are assessed to be detectably different from natural internal climate variability, and these temperature changes are attributed with confidence to climate change induced by anthropogenic effects (Sonali et al. 2018). These assessments are based on detection and attribution studies using observational datasets and the multiple atmosphere-ocean coupled general circulation model (AOGCM) outputs of historical simulation experiments conducted in the fifth phase of the Coupled Model Intercomparison Project
(CMIP5; Taylor et al. 2012), from which human and natural causes of climate change could be identified and quantified.

\subsubsection{Temperature Extremes}

The all India averaged annual frequency of warm days and nights have increased, and cold days and nights have decreased since 1951 (Fig. 2.6 and Table 2.4). These extreme temperature indices are defined from daily temperatures as days when daily maximum (daytime) and mini- 

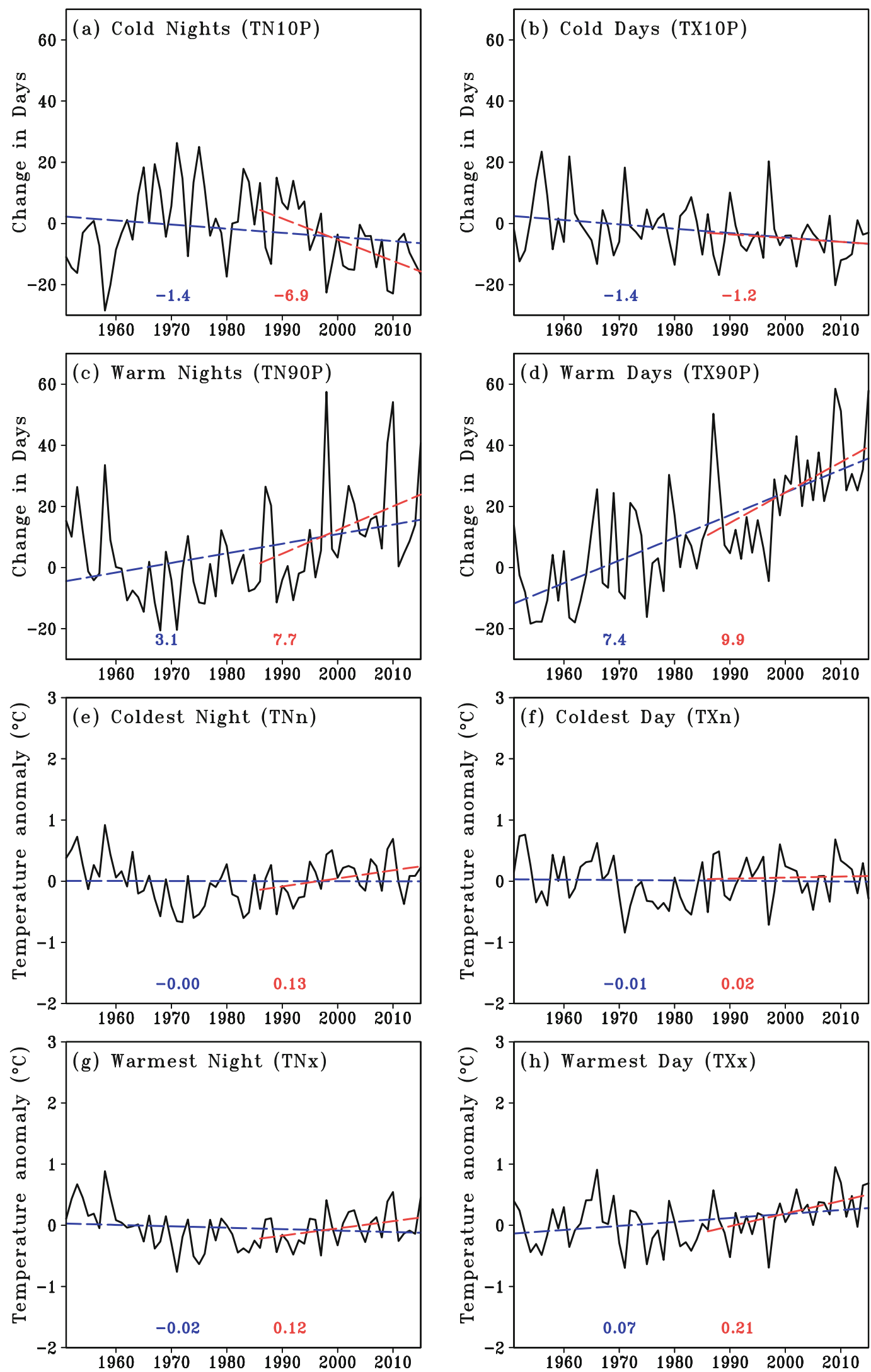

Fig. 2.6 Time-series of all India averaged annual frequency of a cold nights (TN10p), b cold days (TX10p), c warm nights (TN90p), and d warm days (TX90p); and annual intensity of e coldest night (TNn), f coldest day (TXn), $\mathbf{g}$ warmest night $(\mathrm{TNx})$ and $\mathbf{h}$ warmest day (TXx) estimated from the IMD daily gridded maximum and minimum

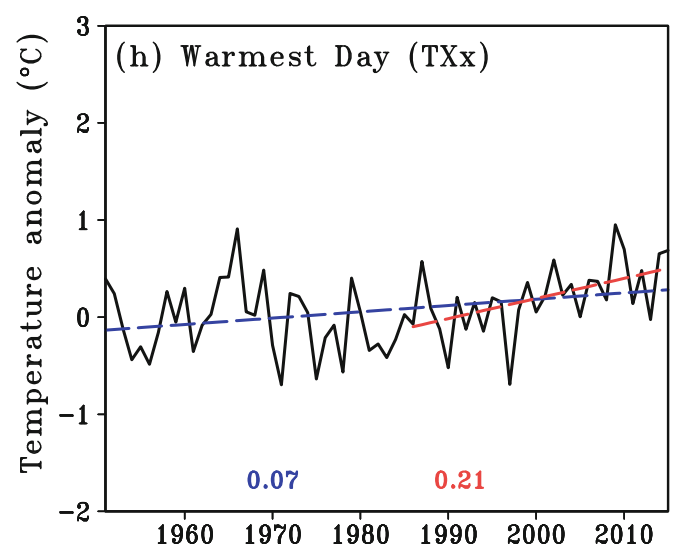

surface air temperature datasets for the period from 1951 to 2015 . The dashed blue and red lines indicate the linear trends for the periods 1951-2015 and 1986-2015, respectively. The rates of changes during these two periods are shown below the trend lines. The $90 \%$ confidence intervals for these trend estimates are assessed in Tables 2.4 and 2.5 
Table 2.4 Observed changes in India land mean annual and seasonal frequency indices of daily extreme temperatures for the periods 1951-2015 and 1986-2015

\begin{tabular}{|c|c|c|c|c|c|c|c|c|}
\hline \multirow[t]{2}{*}{ Season } & \multicolumn{4}{|c|}{ Linear trends $1951-2015$ (days per decade) } & \multicolumn{4}{|c|}{ Linear trends 1986-2015 (days per decade) } \\
\hline & $\begin{array}{l}\text { Cold nights } \\
\text { (TN10p) }\end{array}$ & $\begin{array}{l}\text { Cold days } \\
\text { (TX10p) }\end{array}$ & $\begin{array}{l}\text { Warm } \\
\text { nights } \\
\text { (TN90p) }\end{array}$ & $\begin{array}{l}\text { Warm days } \\
\text { (TX90p) }\end{array}$ & $\begin{array}{l}\text { Cold nights } \\
\text { (TN10p) }\end{array}$ & $\begin{array}{l}\text { Cold days } \\
\text { (TX10p) }\end{array}$ & $\begin{array}{l}\text { Warm } \\
\text { nights } \\
\text { (TN90p) }\end{array}$ & $\begin{array}{l}\text { Warm days } \\
\text { (TX90p) }\end{array}$ \\
\hline Annual & $-1.4 \pm 2.3$ & $-\mathbf{1 . 4}^{*} \pm 1.1$ & $3.1^{*} \pm 2.2$ & $7.4^{*} \pm 1.7$ & $-6.9^{*} \pm 3.8$ & $-1.2 \pm 2.8$ & $7.7^{*} \pm 6.4$ & $9.9^{*} \pm 6.4$ \\
\hline $\begin{array}{l}\text { Winter (Dec- } \\
\text { Feb) }\end{array}$ & $-0.2 \pm 0.5$ & $0.2 \pm 0.4$ & $0.6 \pm 0.6$ & $2.2^{*} \pm 0.7$ & $-0.5 \pm 1.2$ & $0.5 \pm 1.4$ & $1.3 \pm 1.4$ & $3.3^{*} \pm 2.0$ \\
\hline $\begin{array}{l}\text { Pre-monsoon } \\
\text { (Mar-May) }\end{array}$ & $-0.2 \pm 0.6$ & $-0.4 \pm 0.5$ & $0.2 \pm 0.7$ & $1.5^{*} \pm 0.6$ & $-\mathbf{2 . 6}^{*} \pm 1.2$ & $-1.0 \pm 1.4$ & $1.4 \pm 2.2$ & $2.5^{*} \pm 2.4$ \\
\hline $\begin{array}{l}\text { Monsoon } \\
\text { (Jun-Sep) }\end{array}$ & $-0.3 \pm 0.9$ & $-\mathbf{0 . 6}{ }^{*} \pm 0.4$ & $1.7^{*} \pm 0.9$ & $2.4^{*} \pm 0.8$ & $-3.0^{*} \pm 1.5$ & $-0.6 \pm 1.1$ & $3.1^{*} \pm 3.0$ & $1.9 \pm 3.3$ \\
\hline $\begin{array}{l}\text { Post-monsoon } \\
\text { (Oct-Nov) }\end{array}$ & $-\mathbf{0 . 6}{ }^{*} \pm 0.4$ & $-0.6^{*} \pm 0.5$ & $\mathbf{0 . 7 ^ { * }} \pm 0.6$ & $1.3^{*} \pm 0.6$ & $-0.8 \pm 0.8$ & $-0.1 \pm 1.1$ & $1.9 \pm 1.9$ & $2.2 \pm 2.4$ \\
\hline
\end{tabular}

Estimates are derived from the IMD gridded station data. Trends and significance have been calculated as in Table 2.1. Bold values with star sign (*) indicate that trend is significant (i.e. a trend of zero lies outside the $90 \%$ confidence interval)

mum (nighttime) temperatures are above the 90th (warm) or below the 10th (cold) percentile (see more details in Box 2.2).

\section{Box 2.2 Frequency and Intensity Indices of Daily Temperature Extremes}

The all India averaged annual frequency and intensity indices of daily extreme temperatures observed over India during the periods 1951-2015 and 1986-2015 are estimated using the IMD daily maximum and minimum surface air temperature gridded datasets. The percentile indices representing the occurrence of cold nights (TN10p), cold days (TX10p), warm nights (TN90p) and warm days (TX90p) are defined following Zhang et al. (2011), and describe the threshold exceedance rate of days where daily minimum or daily maximum temperature is below the 10th or above the 90th percentile, respectively. The thresholds are based on the annual cycle of the percentiles calculated for a 5-day sliding window centered on each calendar day in the base period 1951-1980. The absolute indices representing the intensity of coldest night (TNn), coldest day (TXn), warmest night (TNx) and warmest day (TXx) are also defined following Zhang et al. (2011), and are presented as annual anomalies from the 1951-1980 climatological mean.

The significant annual increase of warm days (about 7.4 days per decade) is found to be higher than that of warm nights (about 3.1 days per decade) during the period 19512015. The magnitude of the significant annual decrease of cold days (about -1.4 days per decade) is weaker than that of the annual increase in the frequency of warm extremes for this long-term period. The seasonal frequency of warm days and warm nights also increased significantly since 1951, except for warm nights in the pre-monsoon season (Table 2.4). The increase in frequency of warm days during monsoon (about 2.4 days per decade) and winter (about 2.2 days per decade) seasons contribute largely to the highest annual increase in the number of warm days over India since 1951. The recent 30-year period (1986-2015) shows a significant acceleration in the all India averaged annual increase of warm days (about 9.9 days per decade) and warm nights (about 7.7 days per decade) and decrease of cold nights (about -6.9 days per decade). In recent decades, the significant increase of winter season warm days (about 3.3 days per decade) largely contributes to the accelerated annual increase in number of warm days over India since 1986. The significant decreases in the frequency of cold nights during monsoon (about -3.0 days per decade) and pre-monsoon (about -2.6 days per decade) seasons contribute largely to the accelerated annual decrease in number of cold nights over India in this recent period (Table 2.4). The significant increase of pre-monsoon season warm days (about 2.5 days per decade) assessed for the recent period 1986-2015 is consistent with the earlier assessments of a gradual increasing trend in all India averaged warm day frequency during 1970-2005 period (Kothawale et al. 2010b; Revadekar et al. 2012). However, the decreasing trend in cold day frequency reported in these past studies is not significant between 1986 and 2015 (see Table 2.4).

The all India averaged annual intensity of warmest day shows a significant increasing trend (about $0.07{ }^{\circ} \mathrm{C}$ per decade) between 1951 and 2015 (Fig. 2.6 and Table 2.5). The recent 30-year period (1986-2015) shows significant acceleration for the annual increase in the intensity of warmest day (about $0.21{ }^{\circ} \mathrm{C}$ per decade) and warmest night (about $0.12{ }^{\circ} \mathrm{C}$ per decade), and decrease in the intensity of 
Table 2.5 Observed changes in India land mean annual and seasonal intensity indices of daily extreme temperatures for the periods 1951-2015 and 1986-2015

\begin{tabular}{|c|c|c|c|c|c|c|c|c|}
\hline \multirow[t]{2}{*}{ Season } & \multicolumn{4}{|c|}{ Linear trends $1951-2015\left({ }^{\circ} \mathrm{C}\right.$ per decade $)$} & \multicolumn{4}{|c|}{ Linear trends $1986-2015\left({ }^{\circ} \mathrm{C}\right.$ per decade $)$} \\
\hline & $\begin{array}{l}\text { Coldest night } \\
\text { (TNn) }\end{array}$ & $\begin{array}{l}\text { Coldest day } \\
\text { (TXn) }\end{array}$ & $\begin{array}{l}\text { Warmest night } \\
(\mathrm{TNx})\end{array}$ & $\begin{array}{l}\text { Warmest day } \\
(\mathrm{TXx})\end{array}$ & $\begin{array}{l}\text { Coldest night } \\
\text { (TNn) }\end{array}$ & $\begin{array}{l}\text { Coldest day } \\
\text { (TXn) }\end{array}$ & $\begin{array}{l}\text { Warmest night } \\
\text { (TNx) }\end{array}$ & $\begin{array}{l}\text { Warmest day } \\
\text { (TXx) }\end{array}$ \\
\hline Annual & $0.00 \pm 0.07$ & $-0.01 \pm 0.06$ & $-0.02 \pm 0.05$ & $\mathbf{0 . 0 7} \pm 0.05$ & $\mathbf{0 . 1 3} \pm 0.12$ & $0.02 \pm 0.13$ & $\mathbf{0 . 1 2} * 0.10$ & $\mathbf{0 . 2 1} * 0.11$ \\
\hline $\begin{array}{l}\text { Winter (Dec- } \\
\text { Feb) }\end{array}$ & $-0.01 \pm 0.08$ & $-\mathbf{0 . 0 9}^{*} \pm 0.08$ & $-0.01 \pm 0.08$ & $0.02 \pm 0.09$ & $-0.08 \pm 0.19$ & $-0.10 \pm 0.28$ & $\mathbf{0 . 1 7}^{*} \pm 0.14$ & $\mathbf{0 . 2 6}{ }^{*} \pm 0.18$ \\
\hline $\begin{array}{l}\text { Pre-monsoon } \\
\text { (Mar-May) }\end{array}$ & $-0.02 \pm 0.09$ & $-0.02 \pm 0.10$ & $-\mathbf{0 . 0 9}^{*} \pm 0.07$ & $0.05 \pm 0.07$ & $\mathbf{0 . 2 8}^{*} \pm 0.20$ & $-0.03 \pm 0.32$ & $0.10 \pm 0.16$ & $0.29^{*} \pm 0.18$ \\
\hline $\begin{array}{l}\text { Monsoon (Jun- } \\
\text { Sep) }\end{array}$ & $-0.01 \pm 0.05$ & $0.04 \pm 0.05$ & $-0.02 \pm 0.04$ & $\mathbf{0 . 0 9}^{*} \pm 0.06$ & $\mathbf{0 . 1 5} * 0.09$ & $0.10 \pm 0.15$ & $0.05 \pm 0.09$ & $0.12 \pm 0.20$ \\
\hline $\begin{array}{l}\text { Post-monsoon } \\
\text { (Oct-Nov) }\end{array}$ & $0.05 \pm 0.09$ & $0.04 \pm 0.09$ & $0.03 \pm 0.08$ & $0.10 \pm 0.10$ & $0.19 \pm 0.19$ & $0.01 \pm 0.25$ & $0.20 \pm 0.22$ & $0.17 \pm 0.26$ \\
\hline
\end{tabular}

Estimates are derived from the IMD gridded station data. Trends and significance have been calculated as in Table 2.1 . Bold values with star sign $(*)$ indicate that trend is significant (i.e. a trend of zero lies outside the $90 \%$ confidence interval)

coldest night (about $0.13{ }^{\circ} \mathrm{C}$ per decade). The significant increase in the intensity of warmest day during pre-monsoon (about $0.29{ }^{\circ} \mathrm{C}$ per decade) and winter (about $0.26{ }^{\circ} \mathrm{C}$ per decade) seasons contribute largely to the accelerated annual increase in the intensity of the warmest day over India in the recent period (Table 2.5). The annual increase in the intensity of the warmest night is dominated by the significant increases in the winter season (about $0.17{ }^{\circ} \mathrm{C}$ per decade). The significant decrease in the intensity of coldest night during the pre-monsoon (about $0.28{ }^{\circ} \mathrm{C}$ per decade) and monsoon (about $0.15{ }^{\circ} \mathrm{C}$ per decade) seasons contribute to the accelerated annual decrease in the intensity of the coldest night over India during the recent period 1986-2015.

Significant increasing (decreasing) trends in heatwaves (cold waves) are observed during the hot (cold) weather season over most parts of India (Rohini et al. 2016, 2019; Ratnam et al. 2016; Pai et al. 2017). These periods containing consecutive extremely hot days (cold nights) are defined when departure in daily maximum (minimum) temperature exceeds (are below) the objectively defined threshold value (Pai et al. 2017). The observed frequency, total duration and maximum duration of heat waves during the hot summer months (April-June) are increasing over central and north-western parts of India (Rohini et al. 2016). The increase in the number of intensive heat waves between March and June in India over a recent-past decade was attributed to the presence of an upper-level cyclonic anomaly over the west of North Africa and a cooling anomaly in the Pacific (Ratnam et al. 2016). A significant decadal variation was observed in the frequency, spatial coverage and area of the maximum frequency of heat (cold) wave events over India (Pai et al. 2017). The variability of heat waves over India was found to be influenced by both the tropical Indian Ocean and central Pacific sea surface temperature anomalies. A noticeable increase (decrease) in the frequency of heatwave days was observed during the El Nino (La Nina) events. It is also assessed that the spatial extent affected by concurrent meteorological droughts and heatwaves is increasing across India during the period 1981-2010 relative to the base period 1951-1980 (Sharma and Mujumdar 2017).

\subsection{Projected Temperature Changes Over India}

The projected future changes in temperature over India are assessed using the recently available high-resolution regional climate information from CORDEX South Asia and NEX-GDDP datasets generated by downscaling the CMIP5 AOGCM global-scale climate change projections using dynamical (i.e. regional climate modelling) and statistical (i.e. empirical) methods, respectively, (see more details in Box 2.3). The downscaled future projections in temperature are assessed over the Indian land area, by masking out the oceans and territories outside the geographical borders of India, and are reported for two 30-year future periods: 2040-2069 and 2070-2099 relative to the reference baseline period: 1976-2005, representing the mid-term and long-term changes in future climate over India.

Box 2.3 Downscaled High-Resolution CORDEX South Asia and NEX-GDDP Climate Change Projections

The coupled Atmospheric-Ocean General Circulation Models (AOGCMs) are the primary tools used to assess the nature and extent of the anthropogenic changes that are leading to global climate change since 1950s (Bindoff et al. 2013). The AOGCMs 
numerically represent the global climate system, and simulate historical and future climate projections. The most recent Fifth Assessment Report of IPCC (AR5; IPCC 2013) was based on multiple AOGCM outputs that participated in the fifth phase of the Coupled Model Intercomparison Project (CMIP5; Taylor et al. 2012) of the World Climate Research Program (WCRP). The CMIP5 AOGCMs projected distinct increases in temperature over South Asia during the twenty-first century, especially during the winter season (Christensen et al. 2013). These AOGCMs with coarse horizontal resolution $(\sim 100 \mathrm{~km})$ were assessed to have good skill in simulating the regional synoptic-scale circulation pattern and smoothly varying climate variables like temperature. However, the temperature biases were assessed to be larger in few specific regions, particularly at high elevations over the Himalayas (Flato et al. 2013). Also, the assessment of a wide range of regional climate processes and features that are important for capturing the complexity of the Indian summer monsoon rainfall indicated that the performance of the individual AOGCMs varied in the CMIP5 historical experiments depending on which aspect of a model simulation was evaluated (Singh et al. 2017).

The recent developments to generate highresolution regional-scale climate information by downscaling the CMIP5 AOGCM based global-scale climate change projections using statistical (i.e. empirical) and dynamical (i.e. regional climate modelling) methods are used to assess the future changes in temperature over India in Sect. 2.3.

The statistical downscaling approach derives empirical relationships linking large-scale atmospheric variables (predictors) and local/regional climate variables (predictands). These relationships are then applied to equivalent predictors from AOGCMs. The NASA Earth Exchange (NEX) Global Daily Downscaled Projections (GDDP) dataset uses the Bias-Correction Spatial Disaggregation (BCSD) method (Thrasher et al. 2012) to correct the systematic bias of the CMIP5 AOGCM daily maximum and minimum temperature historical data through comparisons performed against the Global Meteorological Forcing Dataset (GMFD; Sheffield et al. 2006), and spatially interpolates the adjusted AOGCM data to the finer resolution grid of the $0.25^{\circ}$ GMFD data. The BCSD approach used in generating this downscaled dataset inherently assumes that the relative spatial patterns in temperature observed from 1950 through 2005 will remain constant for future climate change under the RCP4.5 and RCP8.5 emission scenarios. The limitation of the NEX-GDDP dataset is that other than the higher spatial resolution and bias-correction this dataset does not add information beyond what is contained in the original CMIP5 scenarios, and preserves the frequency of periods of anomalously high and low temperature (i.e. extreme events) within each individual CMIP5 scenario.

The dynamical downscaling derives regional climate information using physical-dynamical relationships by embedding a high-resolution regional climate model (RCM) within a coarse-resolution AOGCM. The WCRP regional activity Coordinated Regional climate Downscaling Experiment (CORDEX; http:// www.cordex.org/) has generated an ensemble of regional climate change projections for South Asia with a high spatial resolution $(50 \mathrm{~km})$ by dynamically downscaling several CMIP5 AOGCM outputs using multiple RCMs. Section 2.3 assess the future changes in the annual mean, maximum and minimum surface air temperature over India using the CORDEX South Asia dynamically downscaled historical simulations and future projections of climate change till the end of the twenty-first century available from the CORDEX data archives on the Earth System Grid Federation (ESGF). This multi-RCM ensemble consists of six simulations with IITM-RegCM4 RCM and ten simulations with SMHI-RCA4 RCM, respectively, under the future RCP4.5 and RCP8.5 emission scenarios, and five simulations with SMHI-RCA4 RCM under the future RCP2.6 emission scenario (see more details in Table 2.6). These dynamically downscaled CMIP5 future temperature projections for India are also compared in Sect. 2.3 with the NEX-GDDP statistically downscaled daily maximum and minimum temperature projections under the RCP4.5 and RCP8.5 emission scenarios available from the NEX-GDDP data archives for the 10 CMIP5 host models that were used to provide lateral and ocean surface boundary conditions for the CORDEX South Asia RCMs (see Table 2.6).

The performance of the CORDEX South Asia multi-RCM historical temperature simulations have been evaluated in several studies (e.g. Mishra 2015; Sanjay et al. 2017a, b; Nengker et al. 2018; Hasson et al. 2018). These dynamically downscaled RCM simulations showed added value relative to their driving CMIP5 AOGCMs in simulating the climatological seasonal and annual spatial patterns of surface air temperature over the South Asia land region, and the climatological amplitude and phase of the annual cycle of monthly mean temperature over central India (Sanjay et al. 2017a). The spatial pattern of 
temperature climatology over the Himalayas for the present climate was simulated exceptionally well even though these RCMs showed a significant cold bias (Nengker et al. 2018). These RCMs showed larger uncertainty of $1-3.6^{\circ} \mathrm{C}$ for simulated temperature in the CORDEX South Asia historical experiments than that of the observations in the Himalayan water towers (e.g. Indus, Ganges and Brahmaputra river basins; Mishra 2015). This evaluation also showed that the RCMs exhibited large cold bias $\left(6-8{ }^{\circ} \mathrm{C}\right)$ and were not able to reproduce the observed warming in the Himalayan water towers. The downscaled seasonal mean temperature in this multi-RCM ensemble was found to have relatively larger cold bias than their driving CMIP5 AOGCMs over the hilly sub-regions within the Hindu Kush Himalayan region (Sanjay et al. 2017b). Also, these downscaled CORDEX South Asia RCMs and their driving CMIP5 AOGCM experiments consistently showed substantial cold (6$10{ }^{\circ} \mathrm{C}$ ) biases for the observed climatology of temperature over the Himalayan watersheds of Indus basin (Jhelum, Kabul and upper Indus basin; Hasson et al. 2018).

\subsubsection{Mean Temperature}

The CORDEX South Asia multi-RCM ensemble mean projected long-term (2070-2099) annual warming exceeds $4{ }^{\circ} \mathrm{C}$ over most parts of India except the southern peninsula, relative to the reference period 1976-2005 under the high (RCP8.5) emission scenario, with relatively higher change exceeding $5{ }^{\circ} \mathrm{C}$ projected in the semi-arid north-west and north India (Fig. 2.7).

The geographical patterns of long-term change remain below $2{ }^{\circ} \mathrm{C}$ relative to the reference period under the low (RCP2.6) emission scenario over most parts of India. The projections of mid-term (2040-2069) change in these CORDEX South Asia multi-RCM ensemble mean indicate modest sensitivity to alternate RCP scenarios over the Indian land area. The projected mid-term annual warming exceed $1{ }^{\circ} \mathrm{C}$ over most parts of the country, with higher warming exceeding $2{ }^{\circ} \mathrm{C}$ projected in the north-west and north India under the medium (RCP4.5) emission scenario (Fig. 2.7). The summer monsoon temperature projections by a small subset of the CORDEX South Asia RCMs had indicated mean warming of more than $1.5{ }^{\circ} \mathrm{C}$ over the central and northern parts of India for the period 2031-2060 under this medium emission scenario (Sanjay et al. 2017a). The CORDEX South Asia multi-RCMs had provided relatively better confidence than their driving CMIP5 AOGCMs in projecting the magnitude of seasonal warming for the hilly sub-region within the Karakoram and north-western Himalaya, with a higher projected change of $5.4{ }^{\circ} \mathrm{C}$ during winter than of $4.9{ }^{\circ} \mathrm{C}$ during summer monsoon season by the end of the twenty-first century under the high (RCP8.5) emissions scenario (Sanjay et al. 2017b). The CORDEX South Asia RCMs and their ensemble had projected statistically significant strong rate of warming (0.03-0.09 ${ }^{\circ} \mathrm{C}$ per year) across all seasons and RCPs over the Indian Himalayan region (Dimri et al. 2018a). The seasonal response to warming with respect to elevation was found to be substantial with December-January season followed by October-November showing the highest rate of warming at higher elevation sites such as the western Himalayas and northern part of central Himalayas.

The earlier assessment of temperature projections for India using the CMIP5 multi-model and multi-scenario ensemble had also suggested that generally in future the northern part of the country will experience higher warming compared to the southern peninsula (Chaturvedi et al. 2012). It was assessed that the areas in the Himalayas and Kashmir will be particularly subject to large warming to the tune of $8{ }^{\circ} \mathrm{C}$ in RCP8.5 by 2099 relative to the pre-industrial baseline (the 1880s). It was concluded that this assessment of a broad range of temperature projections for India, ranging from 1 to $8{ }^{\circ} \mathrm{C}$ during the period 1880-2099 under different RCP scenarios indicated that these regional climate change projections were associated with a range of limitations and uncertainties - driven mainly by the climate model and future scenario uncertainties (Chaturvedi et al. 2012). Also, an earlier study using multiple CMIP5 model outputs together with a single model ensemble assessed that for temperature in most regions within India the component of uncertainty due to model spread tends to be larger than that arising due to natural internal variability, and tends to grow with time (Singh and AchutaRao 2018).

A consistent and robust feature across the downscaled CORDEX South Asia RCMs is a continuation of warming over India in the twenty-first century for all the RCP scenarios (Fig. 2.8). The CORDEX South Asia historical RCM simulations capture the observed interannual variations and the warming trend reasonably well. The all India averaged annual surface air temperature increases are similar for all the RCP scenarios during the first decade after 2005. The warming rate depends more on the specified greenhouse gas concentration pathway at longer time scales, particularly after about 2050. The multi-RCM ensemble mean under RCP2.6 scenario stays around $1.5{ }^{\circ} \mathrm{C}$ above 1976-2005 levels throughout the twenty-first century, clearly demonstrating the potential of mitigation policies. The ensemble 
Table 2.6 List of the 16 CORDEX South Asia RCM simulations driven with 10 CMIP5 AOGCMs

\begin{tabular}{|c|c|c|c|c|}
\hline $\begin{array}{l}\text { CORDEX } \\
\text { South Asia } \\
\text { RCM }\end{array}$ & $\mathrm{RCM}$ description & $\begin{array}{l}\text { Contributing CORDEX } \\
\text { modelling center }\end{array}$ & $\begin{array}{l}\text { Driving CMIP5 AOGCM (see } \\
\text { details at https://verc.enes.org/ } \\
\text { data/enes-model-data/cmip5/ } \\
\text { resolution) }\end{array}$ & $\begin{array}{l}\text { Contributing CMIP5 } \\
\text { modelling center }\end{array}$ \\
\hline \multirow[t]{6}{*}{$\begin{array}{l}\text { IITM-RegCM4 } \\
\text { (6 members) }\end{array}$} & \multirow{6}{*}{$\begin{array}{l}\text { The Abdus Salam International } \\
\text { Centre for Theoretical Physics } \\
\text { (ICTP) Regional Climatic Model } \\
\text { Version } 4 \text { (RegCM4; Giorgi et al. } \\
\text { 2012) }\end{array}$} & \multirow{6}{*}{$\begin{array}{l}\text { Centre for Climate } \\
\text { Change Research } \\
\text { (CCCR), Indian } \\
\text { Institute of Tropical } \\
\text { Meteorology (IITM), } \\
\text { India }\end{array}$} & CCCma-CanESM2 & $\begin{array}{l}\text { Canadian Centre for } \\
\text { Climate Modelling and } \\
\text { Analysis (CCCma), Canada }\end{array}$ \\
\hline & & & NOAA-GFDL-GFDL-ESM2M & $\begin{array}{l}\text { National Oceanic and } \\
\text { Atmospheric } \\
\text { Administration (NOAA), } \\
\text { Geophysical Fluid } \\
\text { Dynamics Laboratory } \\
\text { (GFDL), USA }\end{array}$ \\
\hline & & & CNRM-CM5 & $\begin{array}{l}\text { Centre National de } \\
\text { RecherchesMe'te' } \\
\text { orologiques (CNRM), } \\
\text { France }\end{array}$ \\
\hline & & & MPI-ESM-MR & $\begin{array}{l}\text { Max Planck Institute for } \\
\text { Meteorology (MPI-M), } \\
\text { Germany }\end{array}$ \\
\hline & & & IPSL-CM5A-LR & $\begin{array}{l}\text { Institut Pierre-Simon } \\
\text { Laplace (IPSL), France }\end{array}$ \\
\hline & & & CSIRO-Mk3.6 & $\begin{array}{l}\text { Commonwealth Scientific } \\
\text { and Industrial Research } \\
\text { Organization (CSIRO), } \\
\text { Australia }\end{array}$ \\
\hline \multirow[t]{10}{*}{$\begin{array}{l}\text { SMHI-RCA4 } \\
\text { (10 members) }\end{array}$} & \multirow[t]{10}{*}{$\begin{array}{l}\text { Rossby Centre Regional } \\
\text { Atmospheric Model Version } 4 \\
\text { (RCA4; Samuelsson et al. 2011) }\end{array}$} & \multirow{10}{*}{$\begin{array}{l}\text { Rossby Centre, Swedish } \\
\text { Meteorological and } \\
\text { Hydrological Institute } \\
\text { (SMHI), Sweden }\end{array}$} & ICHEC-EC-EARTH & $\begin{array}{l}\text { Irish Centre for High-End } \\
\text { Computing (ICHEC), } \\
\text { European Consortium (EC) }\end{array}$ \\
\hline & & & MIROC-MIROC5 & $\begin{array}{l}\text { Model for Interdisciplinary } \\
\text { Research On Climate } \\
\text { (MIROC), Japan Agency } \\
\text { for Marine-Earth Sci. \& } \\
\text { Tech., Japan }\end{array}$ \\
\hline & & & NCC-NorESM1 & $\begin{array}{l}\text { Norwegian Climate Centre } \\
\text { (NCC), Norway }\end{array}$ \\
\hline & & & MOHC-HadGEM2-ES & $\begin{array}{l}\text { Met Office Hadley Centre } \\
\text { for Climate Change } \\
(\mathrm{MOHC}), \text { United Kingdom }\end{array}$ \\
\hline & & & CCCma-CanESM2 & CCCma, Canada \\
\hline & & & NOAA-GFDL-GFDL-ESM2M & NOAA, GFDL, USA \\
\hline & & & CNRM-CM5 & CNRM, France \\
\hline & & & MPI-ESM-LR & MPI-M, Germany \\
\hline & & & IPSL-CM5A-MR & IPSL, France \\
\hline & & & CSIRO-Mk3.6 & CSIRO, Australia \\
\hline
\end{tabular}

mean annual India warming exceeds $2{ }^{\circ} \mathrm{C}$ within the twenty-first century under RCP4.5, and the warming exceeds $4{ }^{\circ} \mathrm{C}$ by the end of the twenty-first century under RCP8.5 scenario. The spread in the minimum to maximum range in the projected warming among the CORDEX South Asia RCMs for each RCP scenario (shown as shading in Fig. 2.8) provides a simple, but crude, measure of uncertainty.
A reliable quantitative estimate of all India averaged annual surface air temperature changes and the associated uncertainty range of future temperature projections for India are obtained by incorporating individual model performance and model convergence criteria within a reliability ensemble averaging (REA) methodology (see more details in Box 2.4). 

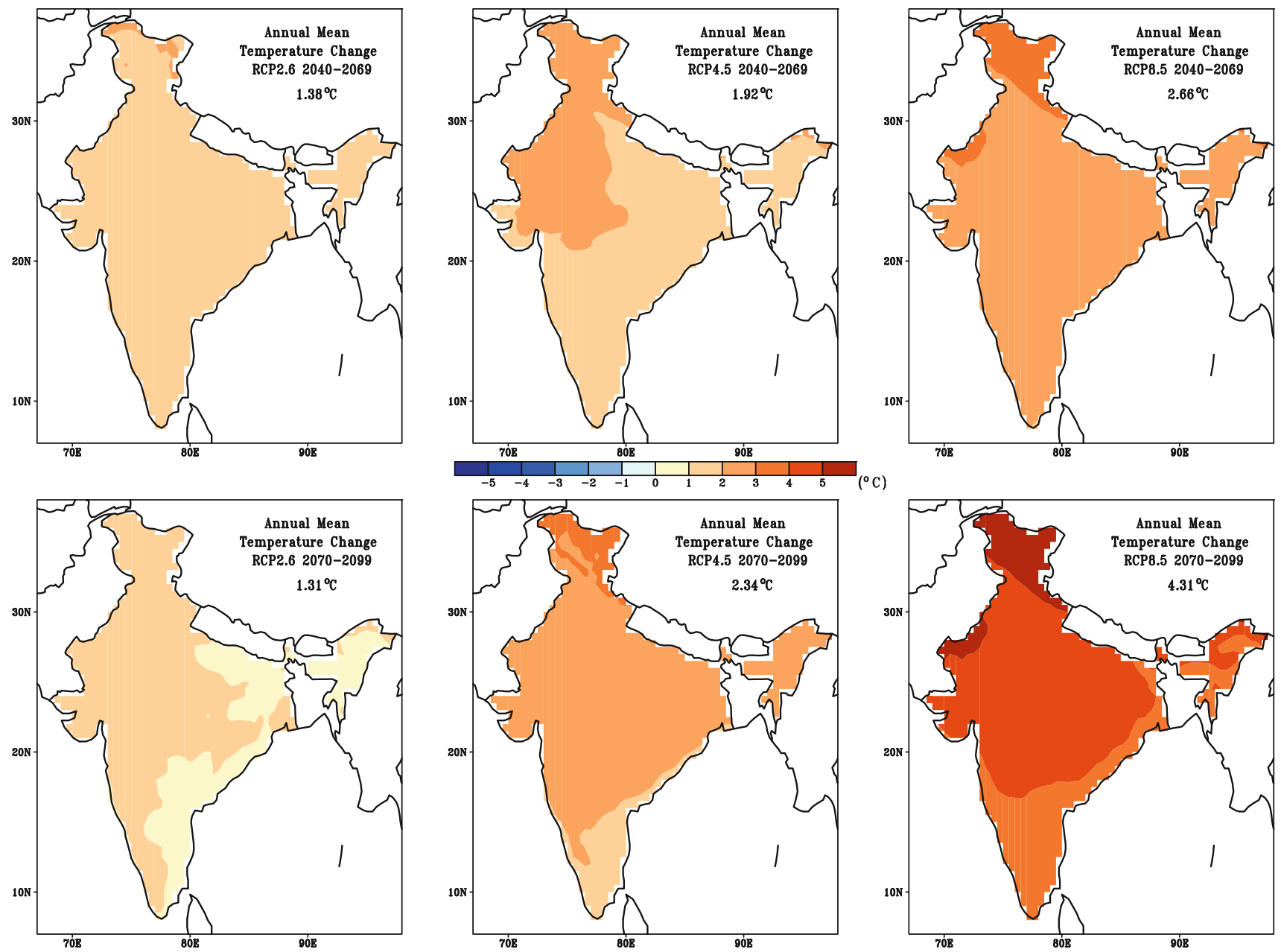

Fig. 2.7 CORDEX South Asia multi-RCM ensemble mean projections of annual average surface air temperature changes (in ${ }^{\circ} \mathrm{C}$ ) over India for the mid-term (2040-2069) and long-term (2070-2099) climate

relative to 1976-2005 under RCP2.6, RCP4.5 and RCP8.5 emission scenarios. The estimates of all India averaged ensemble mean projected changes are shown in each panel

Box 2.4 Climate Model Projections and Weighting The climate change projections for the twenty-first century at the regional or subcontinental spatial scales are based on transient simulations with coupled atmosphere-ocean general circulation models (AOGCMs) including relevant anthropogenic forcings, for example, due to greenhouse gases (GHG) and atmospheric aerosols. These projections have been characterized by a low level of confidence and a high level of uncertainty deriving from different sources: estimates of future anthropogenic forcings, the response of a climate model to a given forcing, the natural variability of the climate system. One of the major sources of uncertainty in future temperature projections is that the different AOGCMs respond differently to the same forcing resulting in differences in the projected changes. These differences are due to the differences in representing the real climate system through a set of mathematically approximated physical, chemical, and biological processes. A recent study assessed that the component of uncertainty due to CMIP5 model spread tends to be larger than that arising due to natural internal variability for temperature in most regions within India, and the model spread tends to grow with time (Singh and AchutaRao 2018). Therefore, a comprehensive assessment of regional change projection needs to be based on the collective information from the ensemble of AOGCM simulations.

A quantitative method called "reliability ensemble averaging" (REA) was introduced by Giorgi and Mearns (2002) for calculating the average, uncertainty range and collective reliability of regional climate change projections from ensembles of different 


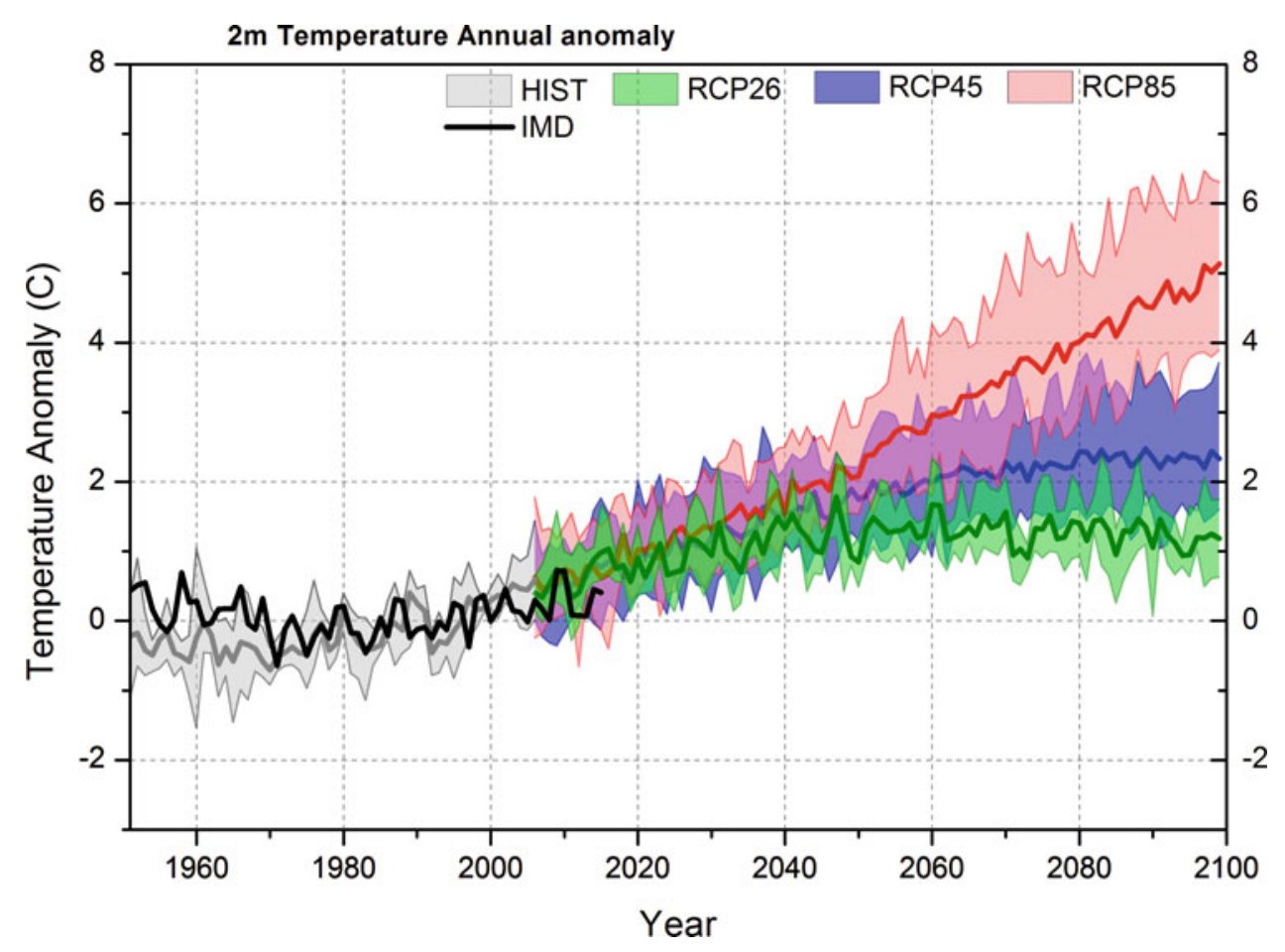

Fig. 2.8 Time series of Indian annual mean surface air temperature $\left({ }^{\circ} \mathrm{C}\right)$ anomalies (relative to 1976-2005) from CORDEX South Asia concentration-driven experiments. The multi-RCM ensemble mean (solid lines) and the minimum to maximum range of the individual RCMs (shading) based on the historical simulations during 1951-2005 (grey), and the downscaled future projections during 2006-2099 are shown for RCP2.6 (green), RCP4.5 (blue) and RCP8.5 (red) scenarios. The black line shows the observed anomalies during 1951-2015 based on IMD gridded station data

AOGCM simulations. This method takes into account two reliability criteria: the performance of the model in reproducing present-day climate and the convergence of the simulated changes across models. The REA average was estimated as the weighted average of the AOGCM ensemble members. The uncertainty range was measured as the root-mean-square difference around the REA average. In the REA method, a model projection is reliable when both its present-day bias and distance from the ensemble average are within the natural variability. When compared to simpler approaches, the REA method estimated a reduction of the uncertainty range in the simulated seasonal temperature and precipitation changes over land regions of subcontinental scale (Giorgi and Mearns 2002). The REA method reduces the uncertainty range by minimizing the contribution of simulations that either performed poorly in the representation of present-day climate over a region or provided outlier simulations with respect to the other models in the ensemble, thus extracting only the most reliable information from each model (Giorgi and Mearns 2002). The use of REA methodology reduced the overall CMIP5 model uncertainty range compared to simpler ensemble average approach for the future projections of surface air temperature and precipitation during the Indian summer monsoon season (Sengupta and Rajeevan 2013). The estimated REA average projected mean monsoon warming was also characterized by consistently high-reliability index in comparison with participating individual CMIP5 AOGCMs.

The results of applying this REA methodology to the dynamically downscaled CORDEX South Asia multi-RCMs and the statistically downscaled NEX-GDDP all India averaged annual surface air temperature changes under the three different RCP scenarios are assessed in Sect. 2.3.1. A measure of natural variability is estimated following Sengupta and Rajeevan (2013) as the difference between the maximum and minimum values of the 30 years moving average of the time series of all India averaged surface air temperature data available from the Indian Institute of Tropical Meteorology (IITM, Pune, http://www. tropmet.res.in) for the period 1901-2005, after linearly detrending the data (to remove century-scale trends). The natural variability in the observed all India 
averaged annual mean, maximum and minimum surface air temperatures are estimated to be $0.347{ }^{\circ} \mathrm{C}$, $0.513{ }^{\circ} \mathrm{C}$ and $0.213{ }^{\circ} \mathrm{C}$ respectively.

The projected REA estimates of warming for the mid-term (2040-2069) ranges between $1.39^{\circ} \mathrm{C}$ under $\mathrm{RCP} 2.6$ scenario to $2.70{ }^{\circ} \mathrm{C}$ under $\mathrm{RCP} 8.5$ scenario (see Table 2.7). The natural variability in the observed all India annual mean surface air temperature is $0.347{ }^{\circ} \mathrm{C}$ (see more details in Box 2.4) while the REA based temperature increases are well above this natural variability estimate. The uncertainty range defined by the root-mean square difference varies in the mid-term between 0.17 and $0.37{ }^{\circ} \mathrm{C}$ for the three RCP scenarios, with the RCP4.5 mid-term warming of $1.92{ }^{\circ} \mathrm{C}$ indicating the maximum uncertainty of $15.6 \%$ (see Table 2.7). The proper weighting of individual CORDEX South Asia RCMs based on their present-day performance by the REA method has resulted in the REA warming under RCP2.6 scenario to be $1.33{ }^{\circ} \mathrm{C}$ above $1976-2005$ levels till the end of the twenty-first century, which is slightly higher than that defined by multi-RCM ensemble mean shown in
Fig. 2.8. However, this estimate of annual warming well below $2{ }^{\circ} \mathrm{C}$ by the end of the twenty-first century for RCP2.6 is found to be associated with the highest uncertainty of $18 \%$ among all the RCP scenarios. The REA estimates of long-term (2070-2099) warming are $2.44 \pm 0.41{ }^{\circ} \mathrm{C}$ and $4.44 \pm 0.45^{\circ} \mathrm{C}$ under RCP4.5 and RCP8.5 scenarios, respectively (see Table 2.7). The assessment of $4.44{ }^{\circ} \mathrm{C}$ warming by the end of the twenty-first century under RCP8.5 scenario is highly reliable as it is associated with the lowest uncertainty (of 10.1\%) among the three RCP scenarios. These CORDEX South Asia multi-RCM ensemble-based temperature projections for India are generally in line with earlier estimates. The CMIP5 ensemble based on 18 models had projected warming of $1.5^{\circ} \mathrm{C}, 2.8^{\circ}$ $\mathrm{C}$ and $4.3{ }^{\circ} \mathrm{C}$ under the RCP2.6, RCP4.5 and RCP8.5 scenarios, respectively, for the 30 year average of 2071-2100 relative to the 1961-1990 baseline (Chaturvedi et al. 2012).

The forced signal of warming occurs not only in the annual mean of daily mean surface air temperature but also in the annual means of daily maximum and daily minimum temperatures (see Tables 2.8 and 2.9). The CORDEX South

Table 2.7 CORDEX South Asia multi-RCM ensemble mean (CDX-ENS) and reliability ensemble average (CDX-REA) estimates of projected changes in annual mean surface air temperature over India relative to 1976-2005, and the associated uncertainty range

\begin{tabular}{l|l|l|l}
\hline Emission scenario & Model ensemble (members) & Annual mean temperature $\left({ }^{\circ} \mathrm{C}\right)$ \\
\cline { 2 - 3 } & & $2040-2069$ & $2070-2099$ \\
\hline RCP2.6 & CDX-ENS(5) & $1.38 \pm 0.17(12.3 \%)$ & $1.31 \pm 0.24(18.3 \%)$ \\
\cline { 2 - 4 } & CDX-REA(5) & $1.39 \pm 0.18(12.9 \%)$ & $1.33 \pm 0.24(18.0 \%)$ \\
\hline RCP4.5 & CDX-ENS(16) & $1.92 \pm 0.30(15.6 \%)$ & $2.34 \pm 0.44(18.8 \%)$ \\
\cline { 2 - 4 } & CDX-REA(16) & $2.03 \pm 0.28(13.8 \%)$ & $2.44 \pm 0.41(16.8 \%)$ \\
\hline & CDX-ENS(15) & $2.66 \pm 0.37(13.9 \%)$ & $4.31 \pm 0.56(13.0 \%)$ \\
\hline & CDX-REA(15) & $2.70 \pm 0.31(11.5 \%)$ & $4.44 \pm 0.45(10.1 \%)$ \\
\hline
\end{tabular}

The values in parenthesis of columns 3 and 4 show the uncertainty range (in \%) measured as the root-mean-square difference around the respective ensemble mean

Table 2.8 CORDEX South Asia multi-RCM ensemble mean (CDX-ENS) and reliability ensemble average (CDX-REA), and NEX-GDDP reliability ensemble average (NEX-REA) estimates of projected changes in annual mean of daily maximum surface air temperature over India relative to $1976-2005$, and the associated uncertainty range

\begin{tabular}{l|l|l|l}
\hline Emission scenario & Model ensemble (members) & \multicolumn{2}{|l}{ Annual maximum temperature $\left({ }^{\circ} \mathrm{C}\right)$} \\
\cline { 2 - 4 } & & $2040-2069$ & $2070-2099$ \\
\hline RCP2.6 & CDX-ENS(5) & $1.29 \pm 0.14(10.9 \%)$ & $1.23 \pm 0.22(17.9 \%)$ \\
\cline { 2 - 4 } & CDX-REA(5) & $1.29 \pm 0.14(10.9 \%)$ & $1.25 \pm 0.23(18.4 \%)$ \\
\hline RCP4.5 & CDX-ENS(16) & $1.79 \pm 0.29(16.2 \%)$ & $2.14 \pm 0.39(18.2 \%)$ \\
\cline { 2 - 4 } & CDX-REA(16) & $1.88 \pm 0.26(13.8 \%)$ & $2.33 \pm 0.37(15.9 \%)$ \\
\cline { 2 - 3 } & NEX-REA(10) & $1.91 \pm 0.28(14.7 \%)$ & $2.35 \pm 0.42(17.9 \%)$ \\
\hline & CDX-ENS(15) & $2.44 \pm 0.34(13.9 \%)$ & $3.93 \pm 0.53(13.5 \%)$ \\
\hline & CDX-REA(15) & $2.59 \pm 0.36(13.9 \%)$ & $4.10 \pm 0.45(11.0 \%)$ \\
\cline { 2 - 4 } & NEX-REA(10) & $2.51 \pm 0.46(18.3 \%)$ & $4.38 \pm 0.65(14.8 \%)$ \\
\hline
\end{tabular}

The values in parenthesis of columns 3 and 4 show the uncertainty range (in \%) measured as the root-mean-square difference around the respective ensemble mean 
Table 2.9 CORDEX South Asia multi-RCM ensemble mean (CDX-ENS) and reliability ensemble average (CDX-REA), and NEX-GDDP reliability ensemble average (NEX-REA) estimates of projected changes in annual mean of daily minimum surface air temperature over India relative to 1976-2005, and the associated uncertainty range

\begin{tabular}{l|l|l|l}
\hline Emission scenario & Model ensemble (members) & \multicolumn{2}{|l}{ Annual minimum temperature $\left({ }^{\circ} \mathrm{C}\right)$} \\
\cline { 2 - 3 } & & $2040-2069$ & $2070-2099$ \\
\hline RCP2.6 & CDX-ENS(5) & $1.49 \pm 0.28(18.8 \%)$ & $1.42 \pm 0.31(21.8 \%)$ \\
\cline { 2 - 3 } & CDX-REA(5) & $1.45 \pm 0.24(16.6 \%)$ & $1.33 \pm 0.27(20.3 \%)$ \\
\hline RCP8.5 & CDX-ENS(16) & $2.09 \pm 0.38(18.2 \%)$ & $2.58 \pm 0.54(20.9 \%)$ \\
\cline { 2 - 4 } & CDX-REA(16) & $2.24 \pm 0.29(12.9 \%)$ & $2.66 \pm 0.38(14.3 \%)$ \\
\hline & NEX-REA(10) & $2.10 \pm 0.30(14.3 \%)$ & $2.38 \pm 0.41(17.2 \%)$ \\
\hline & CDX-ENS(15) & $2.92 \pm 0.45(15.4 \%)$ & $4.77 \pm 0.70(14.7 \%)$ \\
\cline { 2 - 3 } & CDX-REA(15) & $2.90 \pm 0.25(8.6 \%)$ & $4.71 \pm 0.35(7.4 \%)$ \\
\cline { 2 - 4 } & NEX-REA(10) & $2.79 \pm 0.40(14.3 \%)$ & $4.87 \pm 0.55(11.3 \%)$ \\
\hline
\end{tabular}

The values in parenthesis of columns 3 and 4 show the uncertainty range (in \%) measured as the root-mean-square difference around the respective ensemble mean

Asia REA estimate of warming for the two 30 year future periods are lower (higher) for the annual means of daily maximum (minimum) temperature than the respective warming assessed for the annual mean of daily mean temperature under all three RCP scenarios. The REA changes for annual minimum temperature of $4.71 \pm 0.35{ }^{\circ} \mathrm{C}$ (see Table 2.9) is more pronounced than that of $4.10 \pm 0.45{ }^{\circ} \mathrm{C}$ and $4.44 \pm 0.45{ }^{\circ} \mathrm{C}$ increases estimated for all India annual maximum (see Table 2.8) and mean (see Table 2.7) temperatures respectively by the end of the twenty-first century under the high (RCP8.5) emission scenario. The assessment of $4.71{ }^{\circ} \mathrm{C}$ warming for annual mean of daily minimum surface air temperature by the end of the twenty-first century under RCP8.5 scenario is highly reliable as it is associated with the lowest uncertainty (of 7.4\%) among not only the three RCP scenarios for this variable but also for the annual mean and maximum statistic shown in Tables 2.7 and 2.8. This finding illustrates that the dynamically downscaled CORDEX South Asia RCMs based regional climate projections do certainly bring more confidence to future temperature projections for India than the regional climate change information provided by the statistically downscaled NEX-GDDP dataset.

These CORDEX South Asia multi-RCMs had also projected statistically significant higher warming rate $(0.23$ $0.52{ }^{\circ} \mathrm{C} / \mathrm{decade}$ ) for both minimum and maximum air temperatures over the Indian Himalayan region under RCP4.5 and RCP8.5 scenarios (Dimri et al. 2018b).

\subsubsection{Temperature Extremes}

The CORDEX South Asia multi-RCMs project that all India averaged annual frequency of warm nights and warm days will increase from about $10 \%$ in the reference base period (1976-2005) to $80 \%$ and $65 \%$, respectively, by the end of the twenty-first century under the high (RCP8.5) emission scenario (Fig. 2.9). The future changes in the percentile indices based on minimum temperature (warm nights and cold nights) are more pronounced than those based on maximum temperature (warm days and cold days). The downscaled future temperature projections under the high (RCP8.5) emission scenario also indicate that by the end of the twenty-first century there will be virtually no cold nights and cold days over India as defined for the reference base period (1976-2005). The spread among the RCMs (shading in Fig. 2.9) generally becomes smaller as the projection approaches the zero exceedance rates as more models simulate fewer cold nights and cold days. The largest decreases in cold nights and largest increases in warm nights projected over India are typical for tropical regions that are characterized by small day-to-day temperature variability so that changes in mean temperature are associated with comparatively larger changes in exceedance rates below the 10th and above the 90th percentiles.

The CORDEX South Asia multi-RCMs project robust increase (decrease) in the all India averaged annual intensity of warm (cold) temperature extremes by the end of twenty-first century, with the magnitude of the changes increasing with increased anthropogenic forcing (Fig. 2.9). The coldest night of the year warms (about $5.5^{\circ} \mathrm{C}$ ) more than the warmest day (about $4.7^{\circ} \mathrm{C}$ ) over India by the end of the twenty-first century relative to the reference base period (1976-2005) under the high (RCP8.5) emission scenario. This tendency is consistent with the assessment that the increases in the frequency of warm nights are greater than increases in the frequency of warm days.

The CORDEX South Asia multi-RCM ensemble simulate about one heatwave event with an average total duration of about 5 days per summer season (April to June) over India during the historical period 1976-2005 (Fig. 2.10). These heatwave characteristics are identified based on the 90th 

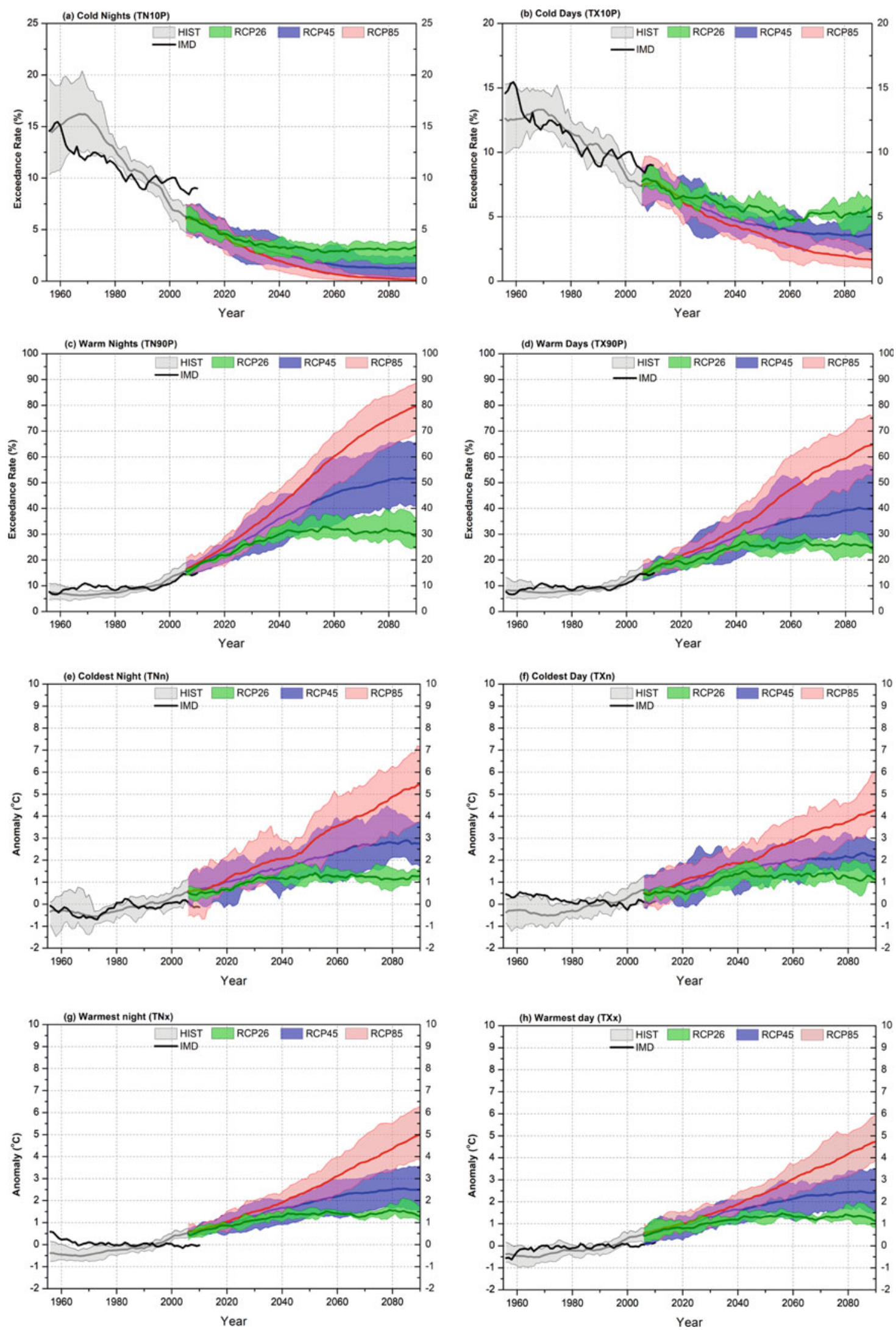
4 Fig. 2.9 India averages of temperature indices over land as simulated by the CORDEX South Asia multi-RCM ensemble (see more details in Table 2.6) for the RCP2.6 (green), RCP4.5 (blue), and RCP8.5 (red) displayed for the annual percentile frequency indices a cold nights (TN10p), b cold days (TX10p), c warm nights (TN90p), and d warm days (TX90p); and for the annual absolute intensity indices e coldest night (TNn), f coldest day (TXn), g warmest night (TNx) and $\mathbf{h}$ warmest day (TXx). Changes for the percentile frequency indices are displayed as absolute exceedance rates (in \%). By construction the exceedance rate averages to about $10 \%$ over the base period 1976 2005. Changes for the absolute intensity indices are displayed as annual anomalies relative to the base period 1976-2005. Solid lines show the ensemble mean and the shading indicates the range among the individual RCMs. The black line shows the observed indices based on IMD gridded station data. Time series are smoothed with an 11-year running mean filter
Fig. 2.10 Time series of all India averaged CORDEX South Asia multi-RCM projections of the summer (April-June) heatwave a frequency (HWF; events per season) and $\mathbf{b}$ total average duration (HWD; days per season) for the CORDEX South Asia RCM ensemble mean (solid lines) and the minimum to maximum range of the individual RCMs (shading) based on the historical simulations during 1951-2005 (grey), and based on the future projections during 2006-2099 under RCP4.5 scenario (blue) and RCP8.5 scenario (red)

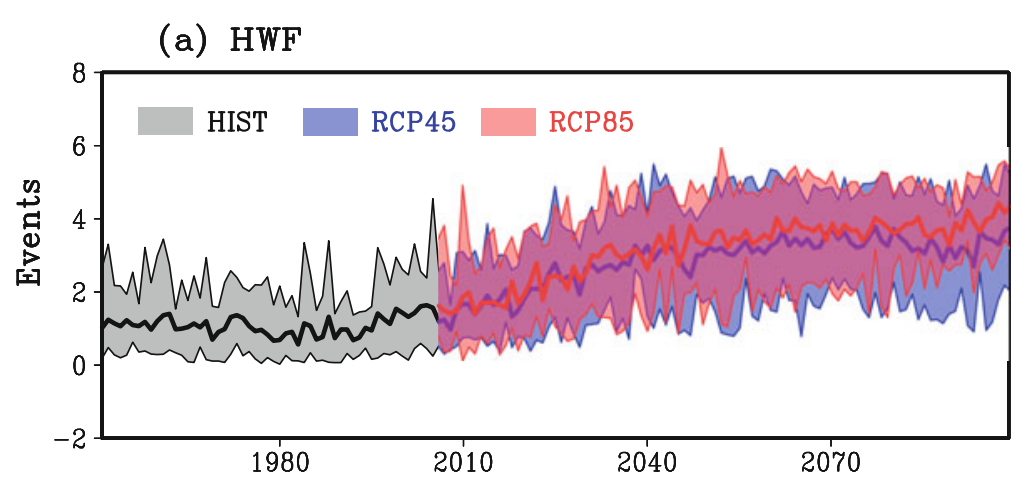

(b) HWD

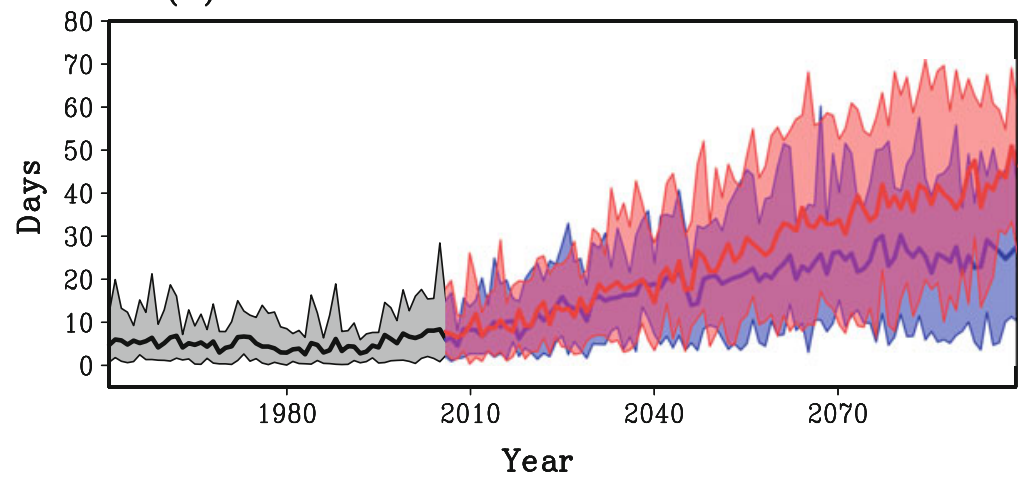

percentile threshold of daily maximum air temperature from each CORDEX model outputs after applying a quantile mapping bias-correction following Lafon et al. (2013), which was based on an empirical distribution correction method (Wood et al. 2004). These findings compare well with the heatwave climatology estimated using the CMIP5 multi-model ensemble and IMD observations over north-west India for the present period (Rohini et al. 2019).

The CORDEX multi-RCM ensemble mean project that all India averaged frequency of summer heatwaves will increase to about 2.5 events per season by the mid-twentyfirst century (2040-2069), with a further slight rise to about 3.0 events by the end-twenty-first century (2070-2099) under the medium (RCP4.5) emission scenario (Fig. 2.10). The average total duration of summer heatwaves is projected to increase to about 15 and 18 days per season during the mid- and end-twenty-first century respectively under this future scenario. The projected increase in these all India averaged summer heatwave characteristics are similar to the assessment based on CMIP5 multi-model ensemble over north-west India in the period 2020-2064 under the RCP4.5 scenario (Rohini et al. 2019). The CORDEX ensemble mean projects that India averaged frequencies of summer heatwaves will increase to about 3.0 and 3.5 events per season during the mid- and end-twenty-first century, respectively under the high (RCP8.5) emission scenario (Fig. 2.10). The future rise in heatwave frequencies under this high emission scenario is marginally higher than the increase in the number of summer events under the RCP4.5 scenario for the corresponding periods. The average total duration of summer heatwaves in India under the RCP8.5 scenario is assessed to be substantially higher than that under RCP4.5 scenario, with about 25 and 35 heatwave days per season during the mid- and end-twenty-first century respectively (Fig. 2.10). The projected CORDEX ensemble mean change in the frequency of heatwaves for the mid- and end-twenty-first century under RCP8.5 scenario relative to the historical reference period (1976-2005) are higher over the north-west region (more than 3 days per summer season) compared to 

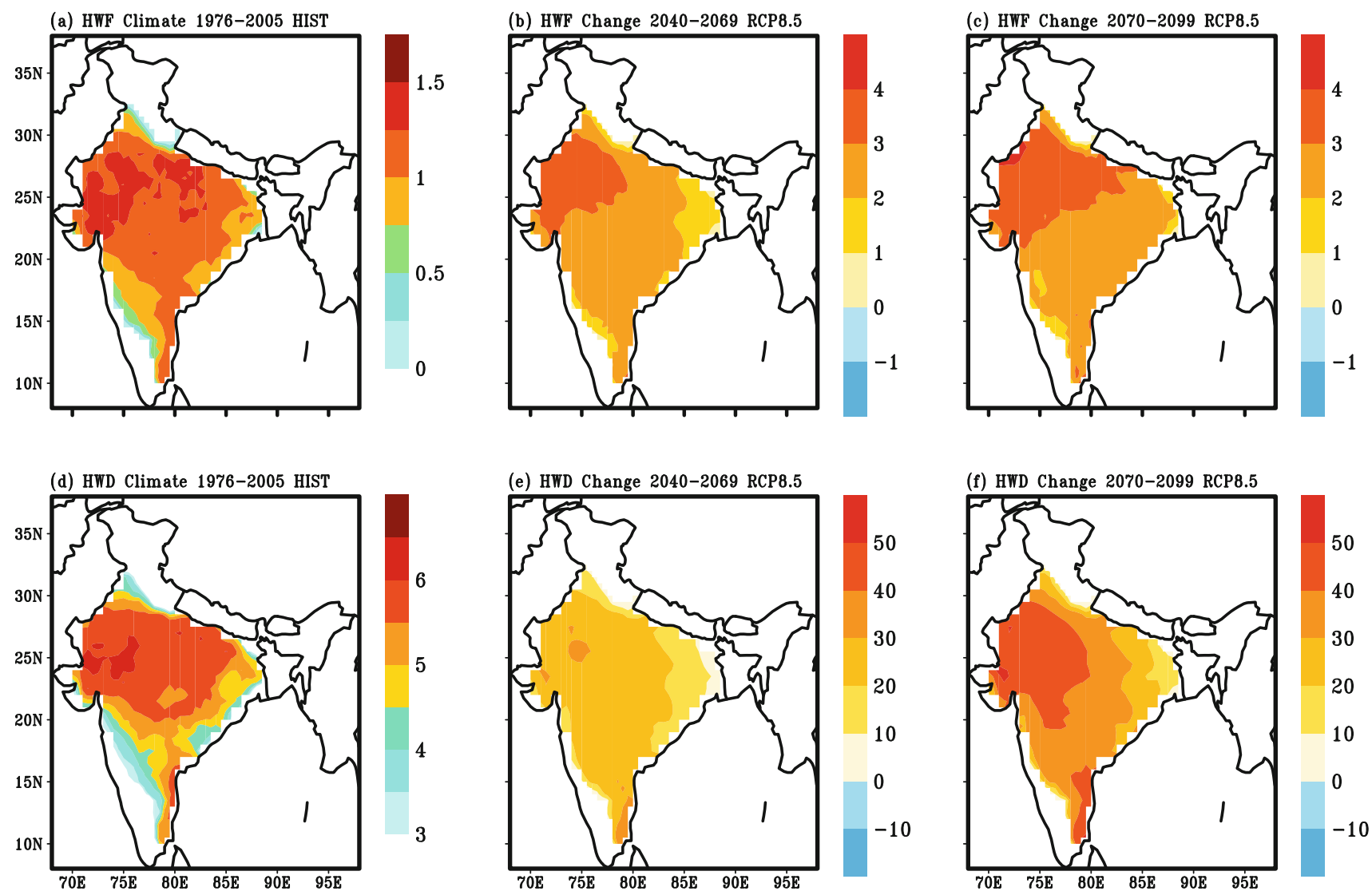

Fig. 2.11 CORDEX South Asia multi-RCM ensemble mean projections of changes in the summer (April-June) heatwave a-c frequency (HWF; events per season) and $\mathbf{d}-\mathbf{f}$ total average duration (HWD; days per season) during the b, e mid-term (2040-2069) and c, f long-term

(2070-2099) climate under RCP8.5 scenario relative to the $\mathbf{a}, \mathbf{d}$ climate for a historical reference period 1976-2005. The projected ensemble mean changes based on 12 CORDEX South Asia RCM are statistically significant at $p$-value $<0.05$

other parts of India (Fig. 2.11). The CORDEX ensemble members consistently project a substantial increase in the average total duration of heat waves of more than 40 days per summer season relative to the historical reference period over north-west India by end of the twenty-first century under this high emission scenario.

These findings are consistent with results based on the CMIP5 multi-model ensemble assessments that the heatwave frequency, duration, intensity and areal coverage over India will substantially increase during the twenty-first century (Murari et al. 2015; Im et al. 2017; Mishra et al. 2017; Russo et al. 2017; Dosio et al. 2018; Rohini et al. 2019). The CMIP5 ensemble had projected that the future warm season (March to June) severe heat waves in India (based on the IMD criteria) will be more intense, with longer durations and will likely occur at a higher frequency and earlier in the year (Murari et al. 2015). The southern India, currently not influenced by heatwaves, is expected to be severely affected by the end of the twenty-first century. Rohini et al. (2016) reported that in near future more frequent and long lasting heatwave events are projected to affect the Indian sub continent in response to the warming of the tropical Indian Ocean (Roxy et al. 2014, 2015) and the increasing frequency of extreme El Nino events (Cai et al. 2015). A CMIP5 multi-model ensemble-based assessment projected 40 times rise in the frequency of severe heat waves over India than in the present climate by the end of the twenty-first century under the RCP8.5 scenario with a heatwave index that captures both duration and magnitude estimated using CMIP5 model projections of all India averaged daily maximum air temperature without bias-correction (Mishra et al. 2017). This study also assessed using a global earth system model ensemble that the projected frequency of severe heatwaves by the end of the twenty-first century will be about 2.5 times lesser (than for RCP8.5 scenario) if the global mean temperature is limited to the low-warming scenario of $2.0^{\circ} \mathrm{C}$ above pre-industrial conditions. However an assessment of the projected population exposure in India due to heat stress (Im et al. 2017) differed considerably from the findings of Mishra et al. (2017) based on a heatwave index without considering the effect of humidity in heatwave estimations. 
The projected future heatwaves based on the extremes of wet-bulb temperature, which includes the effect of humidity, are found to be concentrated around densely populated agricultural regions of the Ganges and Indus river basins (Im et al. 2017). The human populations in these regions highly vulnerable to heat stress are assessed to experience maximum daily wet-bulb temperatures exceeding $31^{\circ} \mathrm{C}$ by 2100 under RCP4.5 scenario, considered dangerous levels for most humans (Im et al. 2017). These extreme wet-bulb temperatures are likely to approach and, in few locations, exceed $35^{\circ} \mathrm{C}$ by the 2070 s under RCP8.5 scenario, considered as an upper limit on human survivability (Coffel et al. 2018). The annual probability of occurrence of heat waves with magnitude greater than the one in Russia in 2010 (the most severe of the present era) at 1.5 and $2{ }^{\circ} \mathrm{C}$ global warming above pre-industrial levels is assessed using CMIP5 ensemble to be different than zero in few parts of India when measured by means of an heatwave index, which takes into account both temperature and relative humidity (Russo et al. 2017). The yearly probability of occurrence of a heatwave at $4^{\circ}$ global warming with magnitude greater than this most severe event in the present period will be greater than $10 \%$ in many parts of India, with the southern peninsula expected to experience such type of humid heatwaves with an annual probability greater than $50 \%$, corresponding to an average return period of two years (Russo et al. 2017).

\subsection{Knowledge Gaps}

To improve the assessment of India's observed and projected warming and its impacts, the following gaps would need to be addressed:

- The uneven spatial distribution of temperature observation sites over India may lead to errors in the assessment of present-day temperature changes, particularly over the northern parts of the country with a very sparse network.

- Confidence in the assessed long-term temperature trends may be constrained by the data inhomogeneity due to changing observation site locations.

- There has been an increase in costly extreme temperature events (e.g. heat waves) across India. Hence urgent research studies are needed on event attribution that evaluates how the probability or intensity of a heatwave event, or more generally, a class of extreme temperature events, has changed as a result of increases in atmospheric greenhouse gases from human activity.

- The CMIP5 multi-model ensemble members sampling structural uncertainty and internal variability cannot be treated as purely independent because some climate models have been developed by sharing model components leading to shared biases. This implies a reduction in the effective number of independent CMIP5 models. The CORDEX South Asia ensemble consists of two RCMs driven by a subset of CMIP5 AOGCMs, implying a very little effective number of independent members in this multi-RCM ensemble.

- The contribution of natural internally generated variability to the total uncertainty in the sub-regional/local temperature projections need to be quantitatively assessed using an ensemble of high-resolution future climate projections for India. The existing ensemble of dynamically downscaled temperature projections from CORDEX South Asia multi-RCMs does not sample initial conditions, which are needed to quantify the contribution of internal variability to the total uncertainty at smaller spatial scales.

- More research is needed to understand whether the increased water vapour under conditions of regional warming is leading to significant positive feedback on human-induced climate change, as water vapour is the most important contributor to the natural greenhouse effect.

- Assessment of joint projections of multiple variables over India are needed to understand the key processes relevant to future projected significant increases in temperature variability and extremes, for example, projected changes by combining mean temperature and precipitation; linking soil moisture, precipitation and temperature mean and variability; combining temperature, humidity, etc.

\subsection{Summary}

In summary, the annual mean, maximum and minimum temperatures averaged over India as a whole show significant warming trend of $0.15{ }^{\circ} \mathrm{C}, 0.15{ }^{\circ} \mathrm{C}$ and $0.13{ }^{\circ} \mathrm{C}$ per decade respectively since 1986 (high confidence). The maximum warming trend is seen during the pre-monsoon season for the recent 30-year period 1986-2015. It is very likely that all India averaged annual and seasonal near-surface air specific humidity have increased since the 1980s. The significant increasing trend in specific humidity assessed during the pre-monsoon season is consistent with the largest surface warming trend found for this season.

The observed surface air temperature changes over India are attributed to anthropogenic forcing (medium confidence). The maximum temperature during the post-monsoon and minimum temperature during the pre-monsoon and monsoon seasons are attributed with confidence to climate change induced by anthropogenic effects (medium confidence).

The all India averaged frequency of warm extremes has increased since 1951 with accelerated warming trends during the recent 30 year period 1986-2015. The annual increase in 
the number of warm days is higher than warm nights, with a relatively milder decrease in number of cold days since 1951. Increase in frequency of warm days during monsoon and winter seasons largely contributed to the observed highest annual increase in number of warm days over India from the mid-twentieth century. The accelerated annual increase in number of warm days and warm nights, and decrease in number of cold nights are observed during 19862015. Increase in frequency of warm days during winter season resulted in the highest annual increase in number of warm days over India during this recent 30 year period. Significant annual warming is observed for the warmest day, warmest night and coldest night since 1986. The warming during pre-monsoon and winter seasons contributed to the strongest warming of the warmest day over India after about 1986.

The all India mean surface air temperature change for the mid-term period 2040-2069 relative to 1976-2005 is projected to be in the range of $1.39-2.70{ }^{\circ} \mathrm{C}$, and is larger than the natural internal variability. This assessment is based on a reliability ensemble average (REA) estimate incorporating each RCM performance and convergence and is associated with less than $13 \%$ uncertainty range. All India mean surface air temperature is projected to increase in the far future (20702099) by $1.33 \pm 0.24{ }^{\circ} \mathrm{C}$ under $\mathrm{RCP} 2.6,2.44 \pm 0.41{ }^{\circ} \mathrm{C}$ under RCP4.5 and $4.44 \pm 0.45{ }^{\circ} \mathrm{C}$ under RCP8.5 scenario, respectively. These changes are relative to the period 19762005. The semi-arid north-west and north India will likely warm more rapidly than the all India mean. The REA changes for all India annual minimum temperature of $4.71 \pm 0.35{ }^{\circ} \mathrm{C}$ is more pronounced than that of $4.10 \pm 0.45^{\circ} \mathrm{C}$ and $4.44 \pm 0.45^{\circ} \mathrm{C}$ increases estimated for the respective annual maximum and mean temperatures, respectively by the end of the twenty-first century under RCP8.5 scenario. The frequency and intensity of warm days and warm nights are projected to increase over India in the next decades, while that of cold days and cold nights will decrease (high confidence). The changes will be more pronounced for cold nights and warm nights. The pre-monsoon season heatwave frequency, duration, intensity and areal coverage over India are projected to increase substantially during the twenty-first century (high confidence).

\section{References}

Bindoff NL, Stott PA, AchutaRao KM, Allen MR, Gillett N, Gutzler D, Hansingo K, Hegerl G, Hu Y, Jain S, Mokhov II, Overland J, Perlwitz J, Sebbari R, Zhang X (2013) Detection and attribution of climate change: from global to regional. In: Stocker TF, Qin D, Plattner DG, Tignor M, Allen SK, Boschung J, Nauels A, Xia Y, Bex V, Midgley PM (eds) Climate change 2013: the physical science basis. Contribution of working group I to the fifth assessment report of the intergovernmental panel on climate change. Cambridge University Press, Cambridge, United Kingdom and New York, NY, USA. p 867-952. https://doi.org/10.1017/ CBO9781107415324.022

Borgaonkar HP, Pant GB, Rupa Kumar K (1994) Dendroclimatic reconstruction of summer precipitation at Srinagar, Kashmir, India since the late 18th century. Holocene 4(3):299-306

Borgaonkar HP, Pant GB, Rupa Kumar K (1996) Ring-width variations in Cedrusdeodara and its climatic response over the western Himalaya. Int J Climatol 16(12):1409-1422

Borgaonkar HP, Somaru Ram, Sikder AB (2009) Assessment of tree-ring analysis of high elevation Cedrusdeodara D. Don from Western Himalaya (India) in relation to climate and glacier fluctuations. Dendrochronologia 27(1):59-69

Borgaonkar HP, Sikder AB, Ram Somaru (2011) High altitude forest sensitivity to the recent warming: a tree-ring analysis of conifers from Western Himalaya India. Quat Int 236(2011):158-166

Borgaonkar HP, Gandhi N, Ram Somaru, Krishnan R (2018) Tree-ring reconstruction of late summer temperatures in northern Sikkim (eastern Himalayas). Palaeogeogr Palaeoclimatol Palaeoecol 504 (1):125-135

Boucher O, Randall D, Artaxo P, Bretherton C, Feingold G, Forster P, Kerminen VM, Kondo Y, Liao H, Lohmann U, Rasch P, Satheesh SK, Sherwood S, Stevens B, Zhang XY (2013) Clouds and aerosols. In: Stocker TF, Qin D, Plattner GK, Tignor M, Allen SK, Boschung J, Nauels A, Xia Y, Bex V, Midgley PM (eds) Climate change 2013: the physical science basis. Contribution of working group I to the fifth assessment report of the intergovernmental panel on climate change. Cambridge University Press, Cambridge, United Kingdom and New York, NY, USA. p 571-658. https://doi.org/10.1017/CBO9781107415324.016

Cai W, Santoso A, Wang G (2015) ENSO and greenhouse warming. Nat Clim Chang 5:849-859. https://doi.org/10.1038/nclimate2743

Chaturvedi RK, Joshi J, Jayaraman M, Bala G, Ravindranath $\mathrm{NH}$ (2012) Multimodel climate change projections for India under representative concentration pathways. Curr Sci 103(7):791-802

Christensen JH, Krishna Kumar K, Aldrian E, An SI, Cavalcanti IFA, de Castro M, Dong W, Goswami P, Hall A, Kanyanga JK, Kitoh A, Kossin J, Lau NC, Renwick J, Stephenson DB, Xie XP, Zhou T (2013) Climate phenomena and their relevance for future regional climate change. In: Stocker TF, Qin D, Plattner GK, Tignor M, Allen SK, Boschung J, Nauels A, Xia Y, Bex V, Midgley PM (eds) Climate change 2013: the physical science basis. Contribution of working group I to the fifth assessment report of the intergovernmental panel on climate change. Cambridge University Press, Cambridge, United Kingdom and New York, NY, USA. p 12171308. https://doi.org/10.1017/CBO9781107415324.028

Coffel ED, Horton RM, de Sherbinin A (2018) Temperature and humidity based projections of a rapid rise in global heat stress exposure during the 21st century. Environ Res Lett 13. https://doi. org/10.1088/1748-9326/aaa00e

Collins M, Knutti R, Arblaster J, Dufresne JL, Fichefet T, Friedlingstein P, Gao X, Gutowski WJ, Johns T, Krinner G, Shongwe M, Tebaldi C, Weaver AJ, Wehner M (2013) Long-term climate change: projections, commitments and irreversibility. In: Stocker TF, Qin D, Plattner GK, Tignor M, Allen SK, Boschung J, Nauels A, Xia Y, Bex V, Midgley PM (eds) Climate change 2013: the physical science basis. Contribution of working group I to the fifth assessment report of the intergovernmental panel on climate change. Cambridge University Press, Cambridge, United Kingdom and New York, NY, USA. p 1029-1136. https://doi.org/ 10.1017/CBO9781107415324.024

Cook ER, Krusic PJ, Jones PD (2003) Dendroclimatic signals in long tree-ring chronologies from the Himalayas of Nepal. Int J Climatol 23:707-732 
Das BK, Gaye B, Malik MA (2010) Biogeochemistry and paleoclimate variability during the Holocene: a record from Mansar Lake lesser Himalaya. Environ Earth Sci 61(3):565-574

Dee DP et al (2011) The ERA-interim reanalysis: configuration and performance of the data assimilation system. Q J R Meteorol Soc 137(656):553-597

Dileepkumar R, AchutaRao K, Arulalan T (2018) Human influence on sub-regional surface air temperature change over India. Sci Rep 8:8967. https://doi.org/10.1038/s41598-018-27185-8

Dimri AP, Kumar D, Choudhary A, Maharana P (2018a) Future changes over the Himalayas: mean temperature. Glob Planet Chang 162:235-251

Dimri AP, Kumar D, Choudhary A, Maharana P (2018b) Future changes over the Himalayas: maximum and minimum temperature. Glob Planet Chang 162:212-234

Dosio A, Mentaschi L, Fischer EM, Wyser K (2018) Extreme heat waves under 1.5 and $2{ }^{\circ} \mathrm{C}$ global warming. Environ Res Lett 13 . https://doi.org/10.1088/1748-9326/aab827

Esper J, Schweingruber FH, Winiger M (2002) 1300 years of climatic history for western central Asia inferred from tree-rings. Holocene 12(3):267-277

Flato G, Marotzke J, Abiodun B, Braconnot P, Chou SC, Collins W, Cox P, Driouech F, Emori S, Eyring V, Forest C, Gleckler P, Guilyardi E, Jakob C, Kattsov V, Reason C, Rummukainen M (2013) Evaluation of climate models. In: Stocker TF, Qin D, Plattner GK, Tignor M, Allen SK, Boschung J, Nauels A, Xia Y, Bex V, Midgley PM (eds) Climate change 2013: the physical science basis. Contribution of working group I to the fifth assessment report of the intergovernmental panel on climate change. Cambridge University Press, Cambridge, United Kingdom and New York, NY, USA. p 741-866. https://doi.org/10.1017/ CBO9781107415324.020

Giorgi F, Coppola E, Solmon F et al (2012) RegCM4: model description and preliminary tests over multiple CORDEX domains. Climate Res 52:7-29

Giorgi F, Mearns LO (2002) Calculation of average, uncertainty range, and reliability of regional climate changes from AOGCM simulations via the 'reliability ensemble averaging' (REA) method. J Clim 15:1141-1158

Harris I, Jones PD, Osborn TJ, Lister DH (2014) Updated high-resolution grids of monthly climatic observations - the CRU TS3.10 Dataset. Int J Climatol 34(3):623-642

Hartmann DL, Klein Tank AMG, Rusticucci M, Alexander LV, Brönnimann S, Charabi Y, Dentener FJ, Dlugokencky EJ, Easterling DR, Kaplan A, Soden BJ, Thorne PW, Wild M, Zhai PM (2013) Observations: atmosphere and surface. In: Stocker TF, Qin D, Plattner GK, Tignor M, Allen SK, Boschung J, Nauels A, Xia Y, Bex V, Midgley PM (eds) Climate change 2013: the physical science basis. Contribution of working group I to the fifth assessment report of the intergovernmental panel on climate change. Cambridge University Press, Cambridge, United Kingdom and New York, NY, USA. p 159-254. https://doi.org/10.1017/ CBO9781107415324.008

Hasson S, Böhner J, Chishtie F (2018) Low fidelity of CORDEX and their driving experiments indicates future climatic uncertainty over Himalayan watersheds of Indus basin. Clim Dyn 52(1):777-798

Hughes MK (2001) An improved reconstruction of summer temperature at Srinagar, Kashmir since $1660 \mathrm{AD}$ based on tree-ring width and maximum latewood density of Abiespindrow (Royle) Spach. Palaeobotanist 50:13-19

Im E-S, Pal JS, Eltahir EAB (2017) Deadly heat waves projected in the densely populated agricultural regions of South Asia. Sci Adv 3 (8): $1-7$

IPCC (2013) Climate change 2013: the physical science basis. In: Stocker TF, Qin D, Plattner G-K, Tignor M, Allen SK, Boschung J,
Nauels A, Xia Y, Bex V, Midgley PM (eds) Contribution of working group I to the fifth assessment report of the intergovernmental panel on climate change. Cambridge University Press, Cambridge, United Kingdom and New York, NY. p 1535. https:// doi.org/10.1017/CBO9781107415324

Jain SK, Kumar V (2012) Trend analysis of rainfall and temperature data for India. Curr Sci 102(1):37-49

Juyal N, Pant RK, Basavaiah N, Bhushan R, Jain M, Saini NK, Yadava MG, Singhvi AK (2009) Reconstruction of Last Glacial to early Holocene monsoon variability from relict lake sediments of the Higher Central Himalaya, Uttrakhand, India. J Asian Earth Sci 34(3):437-449

Kothawale DR, Munot AA, Krishna Kumar K (2010a) Surface air temperature variability over India during 1901-2007, and its association with ENSO. Climate Res 42(2):89-104

Kothawale DR, Revadekar JV, Rupa Kumar K (2010b) Recent trends in pre-monsoon daily temperature extremes over India. J Earth Syst Sci 119:51-65

Kothawale DR, Deshpande NR, Kolli RK (2016) Long term temperature trends at major, medium, small cities and hill stations in India during the period 1901-2013. Am J Clim Chang 5 (3):383-398

Kothawale DR, Singh HN (2017) Recent trends in tropospheric temperature over India during the period 1971-2015. Earth Space Sci 4(5):240-246

Kothawale DR, Rupa Kumar K (2005) On the recent changes in surface temperature trends over India, Geophysical. Res Lett 32. http://doi. org/10.1029/2005GL023528

Krishnan R, Sabin TP, Vellore R, Mujumdar M, Sanjay J, Goswami BN, Hourdin F, Dufresne JL, Terray P (2016) Deciphering the desiccation trend of the South Asian monsoon hydroclimate in a warming world. Clim Dyn 47(3):1007-1027

Krusic PJ, Cook ER, Dukpa D, Putnam AE, Rupper S, Schaefer J (2015) Six hundred thirty-eight years of summer temperature variability over the Bhutanese Himalaya. Geophys Res Lett 42. http://dx.doi.org/10.1002/2015GL063566

Kulkarni A, Deshpande N, Kothawale DR, Sabade SS, Ramarao MVS, Sabin TP, Patwardhan S, Mujumdar M, Krishnan R (2017) Observed climate variability and change over India. In: Krishnan R, Sanjay J (eds) Climate change over India - an interim report. Published by Centre for Climate Change Research, IITM, p 38. http://cccr.tropmet.res.in/home/reports.jsp

Lafon T, Dadson S, Buysa G, Prudhomme C (2013) Bias correction of daily precipitation simulated by a regional climate model: a comparison of methods. Int J Climatol 33:1367-1381

Mishra V (2015) Climatic uncertainty in Himalayan water towers. J Geophys Res Atmos 120(7):2689-2705

Mishra V, Mukherjee S, Kumar R, Stone DA (2017) Heat wave exposure in India in current, 1.5 and $2.0{ }^{\circ} \mathrm{C}$ worlds. Environ Res Lett 12. https://doi.org/10.1088/1748-9326/aa9388

Mukhopadhyay P, Jaswal AK, Deshpande M (2017) Variability and trends of atmospheric moisture over the Indian region. In: Rajeevan MN, Nayak S (eds) Observed climate variability and change over the Indian region, pp 129-144. https://doi.org/10.1007/ 978-981-10-2531-0_8

Murari KK, Ghosh S, Patwardhan A, Daly E, Salvi K (2015) Intensification of future severe heat waves in India and their effect on heat stress and mortality. Reg Environ Change 15(4):569-579

Nengker T, Choudhary A, Dimri AP (2018) Assessment of the performance of CORDEX-SA experiments in simulating seasonal mean temperature over the Himalayan region for the present climate: part I. Clim Dyn 50(7):2411-2441

Padma Kumari B, Goswami BN (2010) Seminal role of clouds on solar dimming over the Indian monsoon region. Geophys Res Lett 37: L06703. https://doi.org/10.1029/2009GL042133 
Padma Kumari B, Londhe AL, Daniel S, Jadhav DB (2007) Observational evidence of solar dimming: offsetting surface warming over India. Geophys Res Lett 34:L21810. https://doi.org/10.1029/ 2007GL031133

Padma Kumari B, Jaswal AK, Goswami BN (2013) Decrease in evaporation over the Indian monsoon region: implication on regional hydrological cycle. Clim Change 121:787-799. https:// doi.org/10.1007/s10584-013-0957-3

Pant GB, Borgaonkar HP, Rupa Kumar K (1998) Climatic signals from tree-rings: a dendro climatic investigation of Himalayan spruce (piceasmithiana). Himalayan Geol 19(2):65-73

Pai DS, Srivastava AK, Smitha Anil Nair (2017) Heat and cold waves over India. In: Rajeevan MN, Nayak S (eds) Observed climate variability and change over the Indian region. Springer Geology, pp 51-71. https://doi.org/10.1007/978-981-10-2531-0_4

Peterson TC, Vose RS, Schmoyer R, Razuvaev V (1998) Global Historical Climatology Network (GHCN) quality control of monthly temperature data. Int J Climatol 18:1169-1179

Rai A, Joshi MK, Pandey AC (2012) Variations in diurnal temperature range over India: under global warming scenario. J Geophys Res 117, D02114. http://doi.org/10.1029/2011JD016697

Ratnam JV, Behera SK, Ratna SB, Rajeevan M, Yamagata T (2016) Anatomy of Indian heat waves. Sci Rep 6, 24395. https://doi.org/10. 1038/srep24395

Revadekar J, Kothawale D, Patwardhan S, Pant G, Kumar K (2012) About the observed and future changes in temperature extremes over India. Nat Hazards 60(3):1133-1155

Rohde R, Muller R, Jacobsen R, Perlmutter S, Rosenfeld A et al (2013) Berkeley earth temperature averaging process. Geoinfor Geostat Overv 1:2. https://doi.org/10.4172/2327-4581.1000103

Rohini P, Rajeevan M, Srivastava AK (2016) On the variability and increasing trends of heat waves over India. Sci Rep 6, 26153. https://doi.org/10.1038/srep26153

Rohini P, Rajeevan M, Mukhopadhay P (2019) Future projections of heat waves over India from CMIP5 models. Clim Dyn 53:975-988. https://doi.org/10.1007/s00382-019-04700-9

Roxy MK, Ritika K, Terray P, Masson S (2014) The curious case of Indian ocean warming. J Clim 27(22):8501-8509

Roxy MK, et al (2015) Drying of Indian subcontinent by rapid Indian ocean warming and a weakening land-sea thermal gradient. Nature Comm 6, 7423. http://doi.org/10.1038/ncomms8423

Rupa Kumar K, Krishna Kumar K, Pant GB (1994) Diurnal asymmetry of surface temperature trends over India. Geophys Res Lett 21:677680

Russo S, Sillmann J, Ster A (2017) Humid heat waves at different warming levels. Sci Rep 7, 7477. http://doi.org/10.1038/s41598017-07536-7

Samuelsson P, Jones CG, Willen U et al (2011) The rossby centre regional climate model RCA3: model description and performance. Tellus 63(1):4-23

Sanjay J, Ramarao MVS, Mujumdar M, Krishnan R (2017a) Regional climate change scenarios. In: Rajeevan MN, Nayak S (eds) Observed climate variability and change over the Indian region. Springer Geology, pp 285-304. https://doi.org/10.1007/978981-10-2531-0_16

Sanjay J, Krishnan R, Shrestha AB, Rajbhandari R, Ren G-Y (2017b) Downscaled climate change projections for the Hindu Kush Himalayan region using CORDEX South Asia regional climate models. Adv Clim Chang Res 8(3):185-198. https://doi.org/10. 1016/j.accre.2017.08.003

Sen Roy S, Balling RC (2005) Analysis of trends in maximum and minimum temperature, diurnal temperature range, and cloud cover over India. Geophys Res Lett 32:L12702. http://doi.org/10.1029/ 2004GL022201
Sengupta A, Rajeevan M (2013) Uncertainty quantification and reliability analysis of CMIP5 projections for the Indian summer monsoon. Curr Sci 105:1692-1703

Sheffield J, Goteti G, Wood EF (2006) Development of a 50-year high-resolution global dataset of meteorological forcings for land surface modeling. J Clim 19(13):3088-3111

Sharma S, Mujumdar P (2017) Increasing frequency and spatial extent of concurrent meteorological droughts and heatwaves in India. Sci Rep 7, 15582. https://doi.org/10.1038/s41598-017-15896-3

Singh S, Ghosh S, Sahana AS, VittalH Karmakar S (2017) Do dynamic regional models add value to the global model projections of Indian monsoon? Clim Dyn 48(3):1375-1397

Singh R, AchutRao K (2018) Quantifying uncertainty in twenty-first century climate change over India. Clim Dyn 52(7):3905-3928

Sonali P, Nanjundiah RS, Kumar DN (2018) Detection and attribution of climate change signals in South India maximum and minimum temperatures. Climate Res 76(2):145-160

Soni VK, Pandithurai G, Pai DS (2012) Evaluation of long-term changes of solar radiation in India. Int J Climatol 32(4):540-551

Srivastava AK, Rajeevan M, Kshirsagar SR (2009) Development of a high resolution daily gridded temperature data set (1969-2005) for the Indian region. Atmos Sci Lett 10(4):249-254

Srivastava AK, Kothawale DR, Rajeevan MN (2017) Variability and long-term changes in surface air temperatures over the Indian subcontinent. In: Rajeevan MN, Nayak S (eds) Observed climate variability and change over the Indian region. Springer Geology, pp 17-35. https://doi.org/10.1007/978-981-10-2531-0_2

Srivastava AK, Revadekar JV, Rajeevan M (2019) South Asia in "State of the climate in 2018". Bull Amer Meteor Soc 100(9):S236-S240. https://doi.org/10.1175/2019BAMSStateoftheClimate.1

Thapa UK, Shah SK, Gaire NP et al (2015) Climate dynamics spring temperatures in the far-western Nepal Himalaya since AD 1640 reconstructed from Piceasmithiana tree-ring widths 45:20692081

Taylor KE, Stouffer RJ, Meehl GA (2012) An overview of CMIP5 and the experiment design. Bull Am Meteorol Soc 93:485-498

Thrasher B, Maurer EP, McKellar C, Duffy PB (2012) Technical note: bias correcting climate model simulated daily temperature extremes with quantile mapping. Hydrol Earth Syst Sci 16(9):3309-3314

Vinnarasi R, Dhanya CT, Chakravorty A, AghaKouchak A (2017) Unravelling diurnal asymmetry of surface temperature in different climate zones. Sci Rep 7(1):1-8. https://doi.org/10.1038/s41598017-07627-5

Willett KM, Gillett NP, Jones PD, Thorne PW (2007) Attribution of observed surface humidity changes to human influence. Nature 449:710-712. https://doi.org/10.1038/nature06207

Willett KM, Dunn RJH, Thorne PW, Bell S, de Podesta M, Parker DE, Jones PD, Williams CN Jr (2014) HadISDH land surface multi-variable humidity and temperature record for climate monitoring. Clim Past 10(6):1983-2006

Wood AW, Leung LR, Sridhar V, Lettenmaier DP (2004) Hydrologic implications of dynamical and statistical approaches to downscaling climate model outputs. Clim Chang 62:189-216

Wu X, Shao X (1995) Status and prospects of dendrochronological study in Tibetan Plateau. Dendrochronologia 13:89-98

Yadav RR, Park WK, Bhattacharya A (1999) Spring temperature variations in the western Himalayan region as reconstructed from tree-rings: AD 1390-1987. Holocene 9(1):85-90

Yadav RR, Braeuning A, Singh J (2011) Tree ring inferred summer temperature variations over the last millennium in western Himalaya, India. Clim Dyn 36(7):1545-1554.

Yadava AK, Yadav RR, Misra KG, Singh J, Singh D (2015) Tree ring evidence of late summer warming in Sikkim, northeast India. Quat Int 371:175-180 
Yasutomi N, Hamada A, Yatagai A (2011) Development of a long-term daily gridded temperature dataset and its application to rain/snow discrimination of daily precipitation. Glob Environ Res 15(2): $165-172$

Open Access This chapter is licensed under the terms of the Creative Commons Attribution 4.0 International License (http:// creativecommons.org/licenses/by/4.0/), which permits use, sharing, adaptation, distribution and reproduction in any medium or format, as long as you give appropriate credit to the original author(s) and the source, provide a link to the Creative Commons license and indicate if changes were made.
Zhang X, Alexander L, Hegerl GC, Jones P, Tank AK, Peterson TC, Trewin B, Zwiers FW (2011) Indices for monitoring changes in extremes based on daily temperature and precipitation data. WIREs Clim Chang 2(6):851-870

The images or other third party material in this chapter are included in the chapter's Creative Commons license, unless indicated otherwise in a credit line to the material. If material is not included in the chapter's Creative Commons license and your intended use is not permitted by statutory regulation or exceeds the permitted use, you will need to obtain permission directly from the copyright holder. 